Ročník XIX (2017), Číslo 2, s. 87-134/ Volume XIX (2017), Issue 2, pp. 87-134

(c) Mezinárodní politologický ústav / International Institute of Political Science DOI: $10.5817 / C E P S R .2017 .2 .87$

\title{
Volební design, reformy a inženýrství v postjugoslávském prostoru 1990-2015
}

\author{
Electoral Design, Reforms, and Engineering in the Post-Yugoslav State \\ Entities, 1990-2015
}

KAREL HÖFER ${ }^{2}$

\begin{abstract}
The article deals with the topic of electoral design, reforms, and engineering in the postYugoslav state entities between 1990 and 2015. First, it briefly conceptualizes a theoretical framework, drawing on the work by Katr, Shugart and Renwick. Second, it describes the evolution of electoral design and reforms to the main chambers in particular systems in detail. Third, it analyses and compares common trends in electoral reforms and design. Proportional representation (PR) list systems have been used for almost $90 \%$ of all 60 elections (a PR list had been adopted by the fourth elections in all the systems). There have been 29 reforms in total (avg. 3.6 per entity), $1 / 5$ of them major and 4/5 minor. Major reforms took place in the Federal Republic of Yugoslavia and in Serbia (one each) and in Croatia and Macedonia (two each). There have, however, been no major electoral reforms in Slovenia, Bosnia and Herzegovina, Montenegro, or Kosovo. Minor reforms have been present in all entities (the most in Bosnia and Herzegovina, and Montenegro, the least in Kosovo and Slovenia). While major reforms were primarily used to correct parts of political systems perceived as dysfunctional, one third of minor reforms were used for intentional electoral engineering. Generally, post-Yugoslav electoral design can be considered unstable, with frequent electoral reforms by the state entities (avg. every 4.7 year). Each system also introduced its specific approach to national minorities, which facilitated their representation in the main chambers.
\end{abstract}

Keywords: Elections; Electoral Design; Electoral Reform; Electoral Engineering; Yugoslavia; Slovenia; Croatia; Bosnia and Herzegovina; Serbia; Montenegro; Kosovo; Macedonia

\footnotetext{
1 Text vznikl v rámci projektu Specifického vysokoškolského výzkumu 2016 č. 260342 „Současné hrozby politického řádu“ realizovaného na Institutu politologických studií Fakulty sociálních věd Univerzity Karlovy. Jeho přepracovaná a aktualizovaná verze vychází z autorova doposud nepublikovaného textu, který byl obhájen jako diplomová a následně jako rigorózní práce na IPS FSV UK. Zde by proto autor rád poděkoval vedoucímu práce Tomášovi Lebedovi a také autorům posudků Ladislavu Cabadovi, Přemyslu Rosůlkovi a Josefu Mlejnkovi, konzultantce Alence Krašovec a také dvěma anonymním recenzentům a redaktorům Pavlovi Dufkovi a Jakubovi Šedovi za cenné rady.

${ }^{2}$ Interní doktorand, Katedra politologie, Fakulta sociálních věd, Univerzita Karlova / Department of Political Science, Faculty of Social Studies, Charles University, Prague, Czech Republic. E-mail: karel.hoefer@fsv.cuni.cz. ORCID iD 0000-0002-4137-3087.
} 


\section{1. Úvod}

Volební systémy (electoral systems) jsou jednou z nejdůležitějších institucí politického systému. Design volebních systémů (electoral design) ale není aktéry vybírán nebo měněn $\mathrm{v}$ nějakém pomyslném vakuu, nýbrž $\mathrm{v}$ kontextu více či méně vyvíjejícího se politického systému. Reformy volebních systémů (electoral reforms) představují jeden z nástrojů, prostřednictvím kterých mohou aktéri aktivně ovlivňovat další podobu či vývoj politického systému jako celku nebo jeho částí. Z tohoto důvodu je tak možné mluvit o volebním inženýrství (electoral engineering) (srov. Reynolds 2000: 59; Blais a Massicotte 2002: 40; Reynolds et al. 2005: 1-7; Norris 2004: 7, 21-22; 261; Gallagher a Mitchell 2008: 3).

Tato studie se konkrétně zaměřuje na volební design, reformy a inženýrství ve volbách do hlavních (dolních) komor parlamentů v postjugoslávských státních entitách mezi léty 1990 a 2015. Postjugoslávský prostor se pritom už na první pohled jeví jako velmi vhodný ke komparativnímu zkoumání. Politické systémy dnes sedmi fakticky samostatných státních entit - Slovinska, Chorvatska, Bosny a Hercegoviny, Srbska, Černé Hory, Kosova, Makedonie - vycházely z velmi podobných institucionálních nastavení $\mathrm{v}$ rámci bývalé Jugoslávie (z hlediska obsazování politických funkcí metodou delegován1), ale jejich vývoj v uplynulých více než 25 letech probíhal nejen z institucionálního hlediska již diferenciovaně, a to včetně nastavení volebních systémů do parlamentů, respektive jejich hlavních komor. Přesto i v této oblasti lze nalézt styčné body, jako je postupný přechod $\mathrm{k}$ využití poměrných systémů nebo speciální př́stup k národnostním menšinám.

Téma volebního designu, reforem a volebního inženýrství v postjugoslávské oblasti bylo prritom již dřive reflektováno např́klad článkem „Electoral Engineering and its Impact in the Former Yugoslav Republics" od Danicy Fink-Hafner, Damjana Lajha a Alenky Krašovec (2011), který se ale místo detailního popisu volebního designu věnoval spíše vlivu na vývoj stranického systému a na demokratizaci, nebo monografiemi Electoral Systems and Political Transformation in PostCommunist Europe Sarah Birch (2003), Volebni systémy postkomunistických zemi Jakuba Šeda (2007) a kolektivní monografií Dietra Nohlena, Philipa Stövera a kol. Elections in Europe: a Data Handbook (2010); ty se ale vzhledem k širšímu teritoriálnímu záběru mohly uvedené problematice věnovat jen ve větší stručnosti. Další publikace k danému tématu, přestože obsahují označení jako východo/jihoevropské, se pak často věnují selektivně jen některým postjugoslávským systémům.

Výzkum proto měl dva hlavní cíle. Prvním bylo systematicky a detailněji popsat, zpřehlednit a vysvětlit vývoj volebního designu a reforem v jednotlivých postujugoslávských politických systémech a doplnit tak stávající informace či případně vyjasnit objevující se nejasnosti. Druhým hlavním a podstatnějším cílem bylo kontextualizovat reformy volebního designu $\mathrm{v}$ jednotlivých politických systémech a na základě jejich typologizace a prostřednictvím následné komparace identifikovat případné trendy ve volebním inženýrství v dané oblasti. 


\section{Konceptualizace výzkumného rámce}

K základní typologizaci volebních reforem lze využít kombinace analytických př́stupů Richarda Katze, Matthewa Shugarta a Alana Renwicka. Katz (2008: 60-73) rozlišuje mezi 1) velkými reformami (major reforms), kdy dochází ke změně typu volebního systému, a 2) malými reformami (minor reforms), kdy dochází ke změnám proměnných $\mathrm{v}$ rámci zachovaného typu volebního systému. ${ }^{3} \mathrm{Na}$ základě př́stupu Matthewa Shugarta (2008) rozlišujícího inherentní a kontingenční faktory lze posléze identifikovat 1) reformy pro reformu, jejichž opravdovým cílem je zvýšit benefity politických aktérů plynoucí z předpokládaných výstupů nového volebního systému, a 2) reformy pro výsledek reformy, jejichž opravdovým cílem je odstranit dysfunkce volebního systému (srov. Chytilek et al. 2009: 104-105). Tento rámec je vhodné doplnit o další aspekt, a to zda reforma byla potenciálně inkluzivní, tedy směrem $\mathrm{k}$ větší proporcionalitě a otevřenosti systému, nebo naopak potenciálně exkluzivní. ${ }^{4}$ Alan Renwick (2011: 457-460) jako možné aktéry volebních reforem uvádí politiky (které je ale vhodnější dále rozlišovat na vládní aktéry, opoziční aktéry, koalici vládních a opozičních aktérů, a v parlamentu nezastoupené aktéry), občany (po upřesnění jde o menší nátlakové skupiny, organizované masy), soudce, externí aktéry (státy nebo mezinárodní organizace), popŕípadě experty. Renwick dále rozlišuje pět ideálních typů procesů volebních reforem podle dominujících aktérů. Konkrétně jde o 1) vnucení masami, 2) aktivní podnět od mas, 3) pasivní podnět od mas, 4) omezení masami, 5) vnucení politickými elitami. U posledního typu pak na základě os míry inkluzivity (vysoká vs. nízká) a koncepce institucí (redistributivní vs. účinné) uvádí tyto podtypy: a) vyjednávání elit, b) dohoda elit, c) vnucení vládní většinou, d) souhlas vládní většiny. ${ }^{5} \mathrm{U}$ všech uvedených typů se ale konkrétní př́pady nalézají spíše v prostoru mezi ideálními typy. ${ }^{6}$

V rámci zkoumání volebního designu a reforem byly ve výzkumu operacionalizovány následující proměnné: typ volebního systému, celkový počet mandátů, počet mandátů rozdělovaných v dané složce systému, typ volebního mechanismu dané složky, počet volebních obvodů, počet mandátů rozdělovaných v jednotlivých obvodech; u poměrných mechanismů navíc: volební formule, uzavírací klauzule, úroveň aplikace uzavírací klauzule, př́padně úroveň dalšího

\footnotetext{
${ }_{3}$ Nejčastěji se podle Katze jedná o změnu volební formule, velikosti obvodů, uzavírací klauzule a počet skrutinií.

4 Podrobně se různým př́stupům ke zkoumání politiky volebních reforem věnuje Charvát (2013: 7 47; 2015a: 11-19; 2015b: 20-47).

${ }^{5}$ Renwick pak dodává, že nejsilnější je tato tendence u typu vyjednávání a dohody mezi politickými elitami, především při přechodech $\mathrm{k}$ demokracii, kdy je nejistá síla aktérů. Naopak v následných reformách $\mathrm{v}$ nových demokraciích podle Renwicka dochází u typu vnucení vládní většinou $\mathrm{k}$ přechodu $\mathrm{k}$ méně proporcionálním systémům. U demokratizujících se a nových demokracií pak Renwick sleduje trend k vyšší personalizaci systémů.

${ }^{6}$ Jak se v průběhu výzkumu ukázalo, tak Renwickův př́stup je značně obecný a arbitrární, tudíž není vhodný pro jakýkoliv typ výzkumu volebních reforem.
} 
přerozdělování, volební formule, typ převedených hlasů, omezení postupu do této úrovně, podoba hlasování. ${ }^{7}$

Vzhledem k tomu, že se volební systémy nevyskytují ve společenském a politickém vakuu, ale jejich design a reformy se prostřednictvím volebního inženýrství odehrávají v politickém (a historickém, kulturním, institucionálním, personálním) kontextu, který následně ovlivňují, musí být alespoň ve stručnosti věnován prostor právě tomuto kontextu. Konkrétně jde o institucionální východiska jugoslávského politického systému, včetně způsobu volby politických reprezentantů; rozpad Jugoslávie a vznik nových státních entit; demokratizaci; státoprávní uspořádání; typ režimů; podobu parlamentů; ústavy a ústavní limity volebního designu; stranické systémy; a pozadí reforem volebního systému. ${ }^{8}$

\section{Institucionální východiska jugoslávského politického systému a politických systémů nově vzniklých státních entit}

V Socialistické federativní republice Jugoslávie $(\mathrm{SFRJ})^{9}$ nebyly povoleny politické strany, nýbrž pouze taxativně vyjmenované společensko-politické organizace, konkrétně Svaz komunistů Jugoslávie (SKJ), ${ }^{10}$ Socialistický svaz pracujícího lidu Jugoslávie, Svaz odborů Jugoslávie, Svaz válečných veteránů národněosvobozeneckého boje Jugoslávie a Svaz socialistické mládeže Jugoslávie. Mezi hlavní opory režimu kromě samotného doživotního vládce Josipa Broze Tita patřil SKJ jako ideologický zdroj moci a hlavní politická síla, Jugoslávská národní armáda (JNA) jako garant bezpečnosti a tajná policie jako zastrašující síla. Navzdory proklamované institucionální decentralizaci byl politický systém centralizován, přičemž na vrcholu stál nejprve Tito a po jeho smrti ústřední výbor SKJ (srov. Pirjevec 2000: 242; Cabada 2015b: 81).

V SFRJ neprobíhaly volby prostřednictvím hlasování a politické orgány na všech úrovních byly obsazovány prostřednictvím metody delegování, která byla

\footnotetext{
7 Podle Lijpharta (1994: 13) by měla být věnována především reformám, kde dochází ke změně volební formule, velikosti uzavírací klauzule (minimálně o $20 \%$ ), velikosti volebních obvodů, celkového počtu poslanců; (srov. Reynolds et al. 2005; Gallagher a Mitchell 2008; Nohlen a Stöver 2010; Rose 2000; Colomer 2004; Norris 2004; LeDuc et al. 2002; Sartori 2001; Chytilek et al. 2009; Lebeda 2008; Novák et al. 2011; Novák, Lebeda et al. 2004; Klíma 1998).

${ }^{8}$ Srov. Freedom in the World (Freedom House 2016), index demokracie v databázi Polity IV (Polity IV Project 2016); Data Page (Integrated Network for Societal Conflict Research 2016]) a Democracy Index (Economist Intelligence Unit 2012); Norris (2004: 39); Hague a Harrop (2010: 251-252, 271-294, 306-307, 319-344); Krulík (2011: 240-242); Romancov (2004: 430-431); Kubát (2011: 711); Reynolds et al. (2005: 7, 20-21, 58-59); Massicotte a Blais (2000: 48); Klíma (1998: 195); Sartori (2005: 125-218); Novák (2011: 565-571); Blais a Massicotte (2002: 40); Colomer (2004: 3-4); Norris (2006: 21-22, 39); Lebeda (2008: 11); Nohlen (2010: 24-25, 41-44, 114-115); Renwick (2010: 85).

${ }^{9}$ Do r. 1963 pod názvem Federativní lidová republika Jugoslávie.

${ }^{10}$ Původně Komunistická strana Jugoslávie.
} 
tamějším univerzálně uplatňovaným principem reprezentace. ${ }^{11}$ Přes deklarovanou ideu delegování jako nástroje samosprávného socialismu vedl tento systém fakticky $\mathrm{k}$ tomu, že občané, kteří nebyli součástí žádné delegace, mohli př́mo volit a rozhodovat pouze o složení delegací na nejnižší úrovni, a byli tak bez reálného vlivu na obsazení a fungování hierarchicky vyšších institucí (srov. Vujica et al. 1980: 84-95; Cabada 2015a: 83-84). Jugoslávii tak mimo jiné z tohoto důvodu nešlo označit v žádné z etap jejího vývoje za demokratický politický systém.

$\mathrm{V}$ rámci SFRJ se vyskytovala na úrovni jednotlivých republik tř́komorová shromáždění skládající se ze sborů sdružené práce, sborů místních společenství a společensko-politických sborů (Socialist Federal Republic of Yugoslavia 1974). Jako nejdůležitější komory v jednotlivých republikách a autonomních oblastech se během tranzice ukázaly společensko-politické sbory (srov. Fink-Hafner, Lajh a Krašovec 2011: 14; Birch 2003: 42, Šedo 2007: 55; Cabada 2005: 118-119). Důvodem bylo především jejich pojetí jako hlavní arény politické (ve smyslu stranické) soutěže.

Po smrti Josipa Broze Tita se národnostní rozpory rozhořely naplno a národnostní štěpení ${ }^{12}$ společně s nacionalismem začalo převažovat nad ostatními štěpeními (srov. Pelikán 2009b: 540-542; Cabada 2008a: 233). Faktory obecně sílících vyhraněných nacionálních tendencí občanů i politiků, drolení moci ve SKJ, neakceschopnosti centrálních institucí a vzájemného soupeření s institucemi republik, obtížného dosažení konsensu na všech úrovních, personálních ambicí vládnoucích i opozičních politiků, ekonomické krize, hroucení socialistických režimů a změny bipolarity mezinárodních vztahů směřovaly $\mathrm{k}$ rozpadu celého státu. SFRJ držel pohromadě především postoj mezinárodního společenství (v čele s Evropským společenstvím a USA) a JNA, která ale byla rozštěpená mezi kliku Slobodana Miloševiće a titoisty (srov. Pelikán 2009b: 575-578).

Pro komunistické funkcionáře bylo snadnější vydobýt si a udržet mocenské pozice na republikové než na federální úrovni. v r. 1990 proběhly první prímé parlamentní volby v SFRJ. Neuskutečnily se ale na centrální úrovni, ale na úrovni jednotlivých republik, a to $\mathrm{v}$ situaci nestrukturovaných, respektive teprve se vytváŕejících, stranických systémů (srov. Sartori 2001: 38-63). Ve Slovinsku zvítězily v dubnu opoziční síly seskupené do DEMOS, v Chorvatsku na přelomu dubna a května opoziční HDZ Franjo Tuđmana, v Makedonii v listopadu nacionalistická VMRO-DPMNE následovaná komunistickou stranou. v Bosně a Hercegovině výsledky listopadových voleb i následné obsazení nejvyšších postů

\footnotetext{
11 V systému delegování obecně o výběru (z) kandidátů rozhodují delegování členové (delegujícî) instituce nebo orgánu, který je hierarchicky, strukturálně i funkcionálně na nižší úrovni než je instituce či orgán, do kterého je kandidát (delegát) vybírán (srov. Chytilek et al. 2009: 14-15; Krejčí 2006: 40-41; Filip a Schelle 1992: 6-8).

12 Ke konceptu štěpení obecně viz Lipset a Rokkan (1967); konkrétněji k (jiho-)východní Evropě pak např́iklad Norris (2004: 253); Dalton (2002: 189-199), Hloušek a Kopeček (2005: 27-30), Klíma (1998: 129), Novák (2011: 557-558).
} 
kopírovaly národnostní složení země, kdy první tři místa obsadily bosňácká SDA, srbská SDS a chorvatské HDZ BiH. v Srbsku v prosinci zvítězila postkomunistická SPS Slobodana Miloševiće a v Černé Hoře Miloševićovi nakloněný (post)komunistický SK CG. ${ }^{13} \mathrm{~V}$ Kosovu pokračovaly protesty proti Miloševićově politice, které vyvrcholily rozpuštěním tamního parlamentu. Následně byl parlament znovu svolán, byla schválena kosovská ústava a proběhlo referendum o samostatnosti Kosova (Pelikán 2009b: 576; Pirjevec 2000: 472).

Během r. 1991 opustili zástupci Slovinska, Chorvatska, Bosny a Hercegoviny a Makedonie federální orgány, které na podzim 1991 ukončily svoji činnost úplně (Pirjevec 2000: 581). Dne 25. června 1991 byla vyhlášena nezávislost Slovinska a Chorvatska. 17. zárí 1991 pak došlo k vyhlášení nezávislosti Republiky Makedonie a 3. března 1992 k vyhlášení nezávislosti Republiky Bosna a Hercegovina. Formálně SFRJ zanikla 27. dubna 1992 ustavením Svazové republiky Jugoslávie (SRJ) skládající se ze Srbska (včetně Vojvodiny a Kosova) a Černé Hory, která byla v r. 2003 přejmenována na Státní společenství Srbsko a Černá Hora (SCG). 3. června 2006 pak došlo k osamostatnění Černé Hory a 17. února 2008 k vyhlášení nezávislosti Kosova.

V prostoru bývalé Jugoslávie probíhaly ozbrojené konflikty; konkrétně šlo o desetidenní válku ve Slovinsku (1991), válku za nezávislost v Chorvatsku (19911995), válku v Bosně a Hercegovině (1992-1995), válku v Kosovu (1998-1999) a povstání v Makedonii (2001). Části území se nejen v rámci těchto konfliktů dostávaly mimo kontrolu a výkon moci centrálních poltických orgánů, jako tomu bylo v prrípadě Republiky Srbská Krajina na území Chorvatska (1990-1995, částečně až do 1998), Černé Hory v SRJ (od 1997) a Kosova na území Srbska respektive SRJ (v různé míře již od roku 1990). Dalším faktorem ovlivňujícím zásadně politickou situaci byly zásahy vnějších aktérů skrze vojenské, policejní či správní mise; tak tomu je v Bosně a Hercegovině (od 1992), v Makedonii (od 1995) a v Kosovu (od 1999).

Z hlediska rychlosti a vývoje demokratizace a stability a konsolidace demokracie se nově vzniklé státní entity i kvưli uvedeným faktorům vyvijely značně odlišně. Ve Slovinsku proběhla demokratizace rychle a bez větších problémů. v Chorvatsku byla demokratizace opožděná kvưli občanské válce mezi Chorvaty a Srby (1992-1995) a režimu, v jehož čele stál až do konce roku 1999 prezident Franjo Tuđman, přičemž poté došlo k poměrně rychlé konsolidaci a stabilizaci demokracie. Ostatní zkoumané systémy ale nelze považovat za zcela konsolidované a stabilní demokracie. Bosnu a Hercegovinu původně kvůli občanské válce (19921995) a poté pokračujícím rozporům mezi jednotlivými (konstitutivními) národy, nerespektování institucionálního rámce zavedeného Daytonskou dohodou,

\footnotetext{
${ }^{13}$ DEMOS - Demokratična opozicija Slovenije; HDZ - Hrvatska demokratska zajednica; VMRO-DPMNE, $\checkmark$ natrě̌na makedonska revolucionerna organizacija-Demokratska partija za makedonsko nacionalno edinstvo; SDA - Stranka demokratske akcije; SDS - Srpska demokratska stranka; HDZ BiH - Hrvatska demokratska zajednica BiH; SPS - Socijalistickea partija Srbije; SK CG - Savez komunista Crne Gore.
} 
prítomnosti rozhodujících vnějších sil v politickém systému a slabé státní identitě (srov. Pelikán 2016: 24-25); Srbsko a Černou Horu, respektive dřive SRJ a SCG, nejprve kvůli účasti země ve válečných konfliktech v Chorvatsku, Bosně a Hercegovině a Kosovu a též kvưli režimu, v jehož čele stál až do roku 2000 nejprve srbský a poté svazový prezident Slobodan Milošević (po r. 2000 pak dochází k postupné demokratizaci obou zemî); Kosovo kvůli konfliktům mezi tamějšími Albánci a Srby, nedosažení kontroly celého území státu (v Severním Kosovu), nerespektování institucionálního rámce srbskou menšinou, propojení politiky s organizovaným zločinem, přítomnosti vnějších sil a také jen částečnému mezinárodnímu uznání; Makedonii kvůli napětí a sporům mezi dvěma největšími politickými stranami etnických Makedonců na levé a pravé části politického spektra a konfliktům mezi tamějšími Makedonci a Albánci.

K rozdílnému vývoji jednotlivých entit došlo také z hlediska státního uspořádání. Unitárním státem s parlamentním režimem jsou Slovinsko, Chorvatsko (do roku 1999 se ale fakticky jednalo spíše o poloprezidentský režim ${ }^{14} \mathrm{~s}$ dominancí prezidenta Franja Tuđmana), Černá Hora (zvykově poměrně silná pozice náleží prezidentovi, rovněž tedy jde spíše o druh poloprezidentského režimu), ${ }^{15}$ Kosovo a Makedonie (poměrně silnou pozici měl v letech 1991-1999 prezident Kiro Gligorov a patrné jsou snahy tamějších Albánců o autonomii). Jako regionální unitární stát lze označit Srbsko, v rámci kterého náleží autonomie Vojvodině a formálně také Kosovu a Metohiji (kde ale Srbsko od r. 1999 nevykonává svoji suverenitu). Srbsko je sice formálně parlamentním režimem, ale silná pozice (ústavně i zvykově) náleží prezidentovi. Proto se fakticky jedná o druh poloprezidentského režimu. ${ }^{16} \mathrm{Za}$ symetrickou federaci s parlamentním režimem lze považovat Bosnu a Hercegovinu skládající se z Republiky srbské (RS) a Federace Bosna a Hercegovina (FBiH) a dř́ve také SRJ (Srbsko ale bylo ve všech ohledech nepoměrně větší a pro politický vývoj směrodatnější než Černá Hora a navíc výsadní postavení v systému zaujímal Slobodan Milošević, v letech 19901997prezident Srbska a 1997-2000 SRJ, takže se také jednalo spíše o druh poloprezidentského režimu s dominancí prezidenta). S transformací SRJ na SCG

\footnotetext{
14 Poloprezidentské režimy lze obecně charakterizovat tak, že exekutivní moc reálně náleží jak premiérovi a vládě, kteří jsou závislí na ne/důvěře parlamentu, tak i prezidentovi volenému občany, který disponuje poměrně rozsáhlými pravomocemi a je nezávislý na důvěře parlamentu, který navíc může rozpustit. Vztah mezi prezidentem a premiérem, respektive vládou, ale záleží na mnoha faktorech, jako je např́klad vymezení pravomocí v ústavě, politické zvyklosti, osobnostní rysy prezidenta, vztah prezidenta $\mathrm{k}$ parlamentní většině, prezidentova politická prŕíslušnost, soudržnost parlamentní většiny atd. (srov. Hague a Harrop 2010: 319-344; Kubát 2011: 711).

15 Prezidentem byl v letech 1990-1998 Momir Bulatović, v l. 1998-2002 Milo Đukanović a od roku 2003 Filip Vujanović.

16 Prezidentem byl v letech 1991-1997 Slobodan Milošević, 1997-2002 Milan Milutinović, 20042012 Boris Tadić a od roku 2012 je jím Tomislav Nikolić.
} 
došlo $\mathrm{k}$ přeměně na konfederaci, přičemž o konfederaci se fakticky jednalo i v závěrečných fázích existence SRJ. ${ }^{17}$

Diferencovaný vývoj nastal také z hlediska podoby parlamentů jednotlivých entit. Unikamerální podobu má v Srbsku, Černé Hoře, Kosovu, Makedonii, od roku 2001 v Chorvatsku a dříve v SCG; asymetricky bikamerální s neprímo volenou horní komorou ve Slovinsku, v Bosně a Hercegovině a v letech 1992-2001 v Chorvatsku; symetricky bikamerální v letech 1992-2003 v SRJ (kromě roku 2000 horní komora volena nepřímo); a konečně trikamerální v letech 1990-1992 ve Slovinsku a Chorvatsku.

\section{Vývoj volebního designu, reforem a inženýrství v jednotlivých státních entitách ${ }^{18}$}

\section{a. Slovinsko}

Slovinský stranický systém lze charakterizovat extrémní multipartismus, respektive dostředivý pluralismus stripolární strukturou, která ale postupně směřuje k bipolární struktuře (Cabada 2003: 265-267; Hloušek 2005: 548; Hloušek 2001), přičemž strany většinou kandidují samostatně. Dominantní stranou systému byla od r. 1991 liberální LDS v čele s Janezem Drnovšekem, jejǐz ústup ale nastal nejpozději v roce 2007 (o čtyři roky později již nezískala ani jeden mandát). Její místo v systému dočasně zaujalo rovněž liberální PS a následně v r. 2014 taktéž liberální SMC. Hlavní stranou pravicového pólu je SDS v čele s Janezem Janšou. Stranou slábnoucího levicového pólu byli SD, jejichž podpora slábla až k pouze těsnému překročení klauzule v r. 2014. Mezi ostatní víceméně stabilně zastoupené strany patří seniorská DeSUS, konzervativní NSi a rolnická SLS. ${ }^{19}$

Design volebního systému pro volby 1990 byl vybrán na základě dohod mezi (post)komunisty a opozicí. (Post)komunisté upřednostňovali kvưli své institucionalizaci většinový systém, opozice naopak kvůli své fragmentaci systém poměrný (Gallenkamp a Kassner 2010: 1764). Vyjednávání na úrovni speciální parlamentní pracovní skupiny skončila kompromisem, kdy byl pro každou ze tří komor přijat jiný volební systém. Pro volby do nejdưležitějš́iho Společenskopolitického sboru byl vybrán poměrný volební systém, aby nebyla zvýhodněna

\footnotetext{
17 Prezident je volen prŕmo ve Slovinsku, Chorvatsku, Srbsku, Černé Hoře, Makedonii (v r. 1991 volen neprímo). Naopak nepřímo jen volen prezident v Kosovu a dříve v SRJ (v r. 2000 zvolen ale přímo). V BiH stojí v čele státu prrímo volené trojčlenné předsednictvo.

${ }_{18}$ Konkrétní parametry jednotlivých volebních designů jsou uvedeny v tabulce č. 8 (viz Př́loha).

${ }^{19}$ LDS - Liberalna demokracija Slovenije (pův. ZSMS - Zveza socialistične mladine Slovenije); LDS - Liberalno demokratska stranka); PS (Pozitivna Slovenija); SMC - Stranka modernega centra (pův. SMC - Stranka Mira Cerarja); SDS - Slovenska demokratska stranka (pův. SDSS/SDS - Socialdemokratska stranka Slovenije); SD Socialni demokrati (pův. ZKS-SDP - Zveza komunistov Slovenije-Stranka demokratične Prenove; ZL - Zdrǔ̌ena lista; ZLSD - Združena lista socialnih demokratov); DeSUS - Demokratična stranka upokojencev; NSi - Nova Slovenija-Kršcanska ljudska strnka; SLS - Slovenska ljudska stranka.
} 
žádná ze skupin (postkomunisté ani opozice si nebyli zcela jisti svými pozicemi) (Cabada 2005: 118; Cabada 2015a: 84-87).

Po prvních volbách v rámci diskuzí o nové podobě ústavy, parlamentu a volebního systému došlo mezi vládnoucími stranami ke kompromisní dohodě na zachování poměrného systému do hlavní komory. Levicové strany pruitom upřednostňovaly spíše poměrný systém a pravicové zase většinový systém. Do ústavy samostatného Slovinska (přijata 1991) bylo přímo zakotveno, že hlavní komora (Státní sbor) se skládá z 90 poslanců, z nichž jeden zastupuje mad’arskou a jeden italskou národnostní menšinu. Reformu volebního systému (velikost, počet obvodů, volební formule, klauzule, další přerozdělování) kromě vládních stran podpořila také část opozice (Cabada 2015a: 90). Podle některých autorů zůstal poměrný systém zachován především $z$ důvodu fragmentovaného stranického systému (Fink-Hafner, Lajh a Krašovec 2011: 14). ${ }^{20}$

V roce 1996 po parlamentních volbách proběhlo referendum o možné reformě volebního systému, ve kterém se občané vyjadřovali ke každé ze tří nabízených variant zvlášt' (volič mohl udělit jeden kladný hlas, ale zároveň mohl hlasovat proti všem návrhům). Největší podíl kladných hlasů získala varianta dvoukolového systému absolutní většiny s 88 jednomandátovými obvody ${ }^{21}$ (Gallenkamp a Kassner 2010: 1767). Pro tuto variantu ale nehlasovala potřebná padesátiprocentní většina zúčastněných voličů. Přesto ústavní soud po dvou letech rozhodl, že má být tento volební systém zaveden. Ani v jednom ze dvou hlasování ve Státním sboru se však v roce 1999 nenašla potřebná dvoutřetinová většina ke schválení návrhu. Středolevicoví poslanci odmítli změnu schválit s odkazem na svoji nezávislost a na chybu soudu (Cabada 2008b: 253; Birch 2003: 32; Cabada 2015b: 97-104). Nakonec byl schválen kompromisní návrh v podobě úpravy poměrného volebního systému a zanesení několika jeho parametrů prímo do textu ústavy. ${ }^{22}$ Do ústavy je tak od r. 2000 př́mo zanesen poměrný volební systém (kromě poslanců národnostních menšin), 4\% volební klauzule (bez uvedení úrovně její aplikace), rozhodující vliv občanů na alokaci mandátu mezi jednotlivými kandidáty a využití Hagenbach-Bischoffovy kvóty. ${ }^{23,24,25}$

\footnotetext{
${ }^{20}$ Nejbližším typem je dohoda politických elit. Cabada (2015a: 94) naproti tomu reformu označuje jako vyjednávání politických elit. Do procesu a také do samotného schválení ale byla začleněna také část opozice, takže se podle autora tohoto textu jednalo spíše o dohodu než o vyjednávání.

${ }^{21}$ Dvoukolový systém absolutní většiny byl skrze petici navržen SDSS v čele s Janezem Janšou, přičemž dalšími variantami byla modifikace poměrného systému navržená LDS a dalšími vládními stranami a poměrný smíšený volební systém navržený Státní radou (Cabada 2015b: 98-99).

22 Pro přijatý návrh hlasovali poslanci LDS, ZL, SNS (Slovenska nacionalna stranka) a SLS, na což ostře reagovala jak SDSS v čele s Janšou, tak i tehdejší premiér Bajuk (Cabada 2005: 201-204)

${ }^{23}$ Hagenbach-Bischoffova kvóta je v zákoně nazývána „Droopovou kvótou“ (Šedo 2007: 57).

24 Přestože politici hráli v procesu hlavní roli, důležitými aktéry byly také organizované masy občanů (referendum) a soudci, ovšem jejich výstupy nebyly př́mo v reformě zavedeny (Cabada 2015a: 109).

${ }^{25}$ Přestože se ve Slovinsku objevují návrhy na změnu poměrného volebního systému (na většinový), poměrný systém zůstal zachován - především kvưli fragmentaci stranického systému, souhlasu dvou
} 


\section{b. Chorvatsko}

Chorvatský stranický systém lze charakterizovat jako extrémní multipartismus, respektive jako dostředivý pluralismus s bipolární strukturou. Do roku 2000 byl však systém polosoutěživý ${ }^{26}$ s predominantním HDZ. Pravicový pól je představován právě konzervativní HDZ a levicový pól SDP. Tyto dvě strany ve volbách získávají celkem kolem dvou třetin mandátů. Ostatní strany sice získávají mandáty $\mathrm{v}$ řádech jednotek, ale jejich důležitost spočívá především $\mathrm{v}$ roli při sestavování koaličních vlád. (srov. Šedo 2010b: 73-84; Pelikán 2009a: 610-611; Hloušek 2008: 272) Mezi další významnější strany patří liberální HNS, regionální HDSSB a IDS a dříve také liberální HSLS, agrární HSS či nacionalistická HSP. Strany často kandidují videologicky vymezených koalicích, kdy se některé $\mathrm{z}$ uvedených stran přidávají do koalic k HDZ nebo SDP. ${ }^{27}$

Design volebního systému pro volby do Společensko-politické rady byl v roce 1990 vybrán (post)komunisty. Ti preferovali dvoukolový většinový systém s polouzavřeným druhým kolem $z$ důvodu slabé institucionalizace vznikajících stran a též vzhledem k poměrně brzkému konání voleb (Kasapović 2010b: 401).

V devadesátých letech využívalo HDZ v čele s Tuđmanem nástrojů volebního inženýrství, které mu měly zajistit a skutečně zajistily zisk většiny mandátů. Přímo do textu ústavy samostatného Chorvatska přijaté na konci roku $1990^{28}$ bylo zaneseno, že hlavní komora se skládá z nejméně 100 a nejvíce ze 160 poslanců, a také to, že chorvatští občané pobývající v zahraničí mají právo volit své zástupce. Design volebního systému pro volby 1992 byl schválen jen čtyři měsíce před konáním voleb a pro volby v r. 1995 pouze měsíc a půl před uskutečněním voleb (Hloušek 2004: 147-148). HDZ v r. 1992 pro volby do Poslanecké sněmovny zavedlo smíšený paralelní systém s vyrovnaným počtem mandátů v obou složkách (poměrný listinný a jednokolový většinový systém) a pěti mandáty pro národnostní menšiny. Přičemž menšiny s více jak $8 \%$ podílem na obyvatelstvu (tj. Srbové) měly být zastoupeny proporčně; v roce 1992 mělo jít o 13 mandátů. Protože Srbové ale nezískali uvedených 13 mandátů ve výše uvedených složkách, měla se o tento počet navýšit celková velikost shromáždění. Tyto mandáty byly obsazeny Srby

třetin poslanců nutnému pro změnu a také kvůli zakotvení systému v ústavě (Fink-Hafner, Lajh a Krašovec 2011: 14-15).

${ }^{26} \mathrm{~V}$ polosoutěživých volbách není voličům možnost výběru mezi více kandidáty zcela upřena, ale je značně omezena především z pohledu plnohodnotné účasti opozice ve volbách a její možností dosáhnout významného výsledku. Takové volby slouží především ke stabilizaci nedemokratického režimu prostřednictvím snahy o legitimizaci mocenských struktur, zmírnění napětí ve společnosti, vylepšení pověsti na mezinárodní scéně, odhalení opozice a její částečné integraci nebo přizpůsobení mocenské struktury (Nohlen 2010: 18).

27 SDP - Socijaldemokratska partija Hrvatske (dříve: SKH-SDP - Savez komunista Hrvatske - Stranka demokratskih promjena; SDP - Stranka demokratskih promjena); HNS - Hrvatska narodna stranka; HDSSB - Hrvatski demokratski savez. Slavonije i Baranje; IDS - Istarski demokratski sabor, HSLS - Hrvatska socijalno-liberalna stranka; HSS - Hrvatska seljačka stranka; HSP - Hrvatska stranka prava.

28 Podstatně novelizována pak byla v letech 1997, 2000, 2001 a 2010. 
z kandidátních listin, které překonaly vstupní klauzuli. ${ }^{29}$ HDZ chtělo reformou především zamezit spolupráci opozice ve 2 . kole voleb ve dvoukolovém většinovém systému a třŕštění národních sil (Šedo 2010b: 74; Rychlík 2016a: 253254).

V r. 1995 se HDZ chtělo vyhnout přímé konfrontaci s opozicí ve většinové složce, a proto byl počet „většinových“ mandátů snížen z 60 na 28 (a počet mandátů poměrné složky zvýšen z 60 na 80) (Kasapović 2000: 9). Navíc byl vytvořen speciální obvod pro voliče chorvatské diaspory. Počet mandátů v tomto obvodu byl značně vyšší, než by měl být podle počtu voličů (Šedo 2007: 213-214). Přes poměrný způsob rozdělování mandátů $\mathrm{v}$ této složce připadly všechny mandáty $z$ tohoto obvodu HDZ, protože pro něj (podle předpokladů) hlasovali především Chorvati z Bosny a Hercegoviny (Rychlík 2016a: 264). v rámci reformy ale došlo také $\mathrm{k}$ dalším úpravám volebního designu (celkový počet mandátů, uzavírací klauzule, počet mandátů a způsob volby Srbů a počet mandátů pro další menšiny).

$\mathrm{Na}$ podzim r. 1999 probíhaly diskuze mezi HDZ a opozicí o podobě volebního systému pro nadcházející volby. Pokusy o sestavení komise složené z HDZ i opozice ale byly neúspěšné. Jedním z nejvíce diskutovaných prvků volebního systému byl dvanáctimandátový obvod diaspory nereflektující průměrný počet hlasujících na jeden mandát (Kasapović 2000: 6). HDZ, kterému v parlamentu náleželo téměř $60 \%$ mandátů, preferovalo poměrný volební systém z důvodu poklesu své popularity, což bylo zapríććněno mj. nemocí Franja Tuđmana, vyřešenou otázkou státních hranic a konfliktu se Srbskem, neuspokojivou ekonomickou situací a tlakem opozice na demokratizaci režimu. Naopak opozice preferovala zachování smíšeného volebního systému, protože její preference sílily. Nakonec byl schválen návrh reformy HDZ na poměrný listinný volební systém (velikost obvodu diaspory podle průměrného počtu hlasů na jeden mandát $\mathrm{v}$ základních obvodech). Volební reforma byla vi̊bec posledním aktem podepsaným Tuđmanem před jeho smrtí (Hloušek 2008: 274; Rychlík 2016a: 268). Tato reforma prakticky znamenala, že HDZ si prestalo nárokovat většinové poslání (Nový a Havlík 2012: 76).

V rámci přijetí nového zákona o právech menšin a vypořádání se se soudní judikaturou došlo pro volby 2003 ke zvýšení počtu poslanců srbské menšiny a redefinování ostatních národnostních menšin. Pro reformu kromě vládních stran hlasovaly i některé opoziční strany, ale bez HDZ a z něho odštěpených stran (Songstad 2004: 8). Pro volby 2011 došlo ke kompromisní dohodě ve věci obvodu diaspory mezi HDZ, které chtělo zachovat co největší obvod, a SDP, která naopak chtěla obvod úplně zrušit (Kasapović 2012: 785). Počet mandátů volebního

\footnotetext{
29 Některé zdroje uvádí, že doplňujícími volbami byli zvoleni tři poslanci, ale volební komise v korespondenci uvádí, že všechny mandáty srbské menšiny byly doplněny z celostátních kandidátních listin v rámci poměrně složky. Pokud by takto nemohlo dojít k obsazení všech mandátů, měly se konat doplňující volby prostřednictvím poměrného listinného systému.
} 
obvodu diaspory byl prostřednictvím zanesení do ústavy stanoven nově na tř̀ mandáty; celkový počet poslanců je stanoven ústavou přesně na 151.

Jedním z cílů v roce 2013 založené pravicově orientované občanské iniciativy Ve jménu rodiny ( $U$ ime obitelji) bylo dosáhnout vypsání referenda mj. o změně podoby hlasování, nových kritériích pro stanovení volebních obvodů, snížení uzavírací klauzule z $5 \%$ na $3 \%$, zákazu předvolebních koalic a společných kandidátek a zavedení distančního a elektronického hlasování. Pro vypsání referenda ale nenasbírala dostatek podpisů a proti jeho uskutečnění navíc byly jak SDP, tak HDZ (Podolnjak 2015: 118). SDP ale nakonec umožnění preferenčního hlasování prosadila parlamentní cestou, přičemž HDZ se zdrželo (Keating 2015). $\mathrm{v}$ roce 2015 tak byla zavedena flexibilní kandidátní listina (Organization for Security and Co-operation in Europe 2016).

\section{c. Bosna a Hercegovina}

Stranický systém Bosny a Hercegoviny lze charakterizovat jako atomizovaný multipartismus, respektive jako polarizovaný pluralismus s tripolární strukturou. Fakticky se ale jedná o dva (FBiH a RS), ale spíše až tři (bosňácký, srbský, chorvatský) stranické systémy, které se setkávají na celostátní (tj. entitní) úrovni. Všechny strany jsou tedy obdobně národnostně vymezeny (srov. Žíla 2016: 115) a nové strany většinou vznikají vydělením se z pưvodních stran. Bosňácký pól je reprezentován především konzervativní SDA, srbský nacionálněsociálnědemokratickým SNSD a konzervativní SDS, chorvatský konzervativním HDZ BiH a z něj odštěpeným HDZ 1990. Potenciální čtvrtý pól se nevymezuje nacionalisticky (a navazuje na postkomunistické vymezení), ale jeho složení a podpora je téměř výhradně bosňácká. Jedná se především o sociálnědemokratickou SDP $\mathrm{BiH}$, liberální $\mathrm{SBiH}, \mathrm{SBB}$ v čele s podnikatelem Fahrudinem Radončićem a DF v čele s Željkem Komišićem. Ve volbách strany kandidují většinou samostatně (srov. Šedo 2010a: 89; Prtina 2005: 32; Manning 2004: 71-72)..$^{30}$

Pro volby do bosensko-hercegovinské Rady občanů byl v r. 1990 zvolen poměrný listinný systém, přičemž podrobnosti o jeho výběru nejsou známy. Volební design pro volby v letech 1996, 1998 a 2000 byl zaveden na základě Daytonské dohody Provizorní volební komisí Mise Organizace pro bezpečnost a spolupráci v Evropě (OSCE) v Bosně a Hercegovině (Kasapović 2010a: 324), tedy vnějšími aktéry. Př́mo do ústavy, která byla oktrojována v roce 1995 jako př́loha Daytonské dohody, je zaneseno, že Sněmovna reprezentantů se skládá ze

\footnotetext{
30 SNSD - Savez, nezavisnih socijaldemokrata; HDZ BiH 1990 - Hrvatska demokratska zajednica 1990; SDP BiH - Socijaldemokratska partija BiH - Socijaldemokrati (dříve: SKH BiH-SDP - Savez komunista BiH - Stranka demokratskih promjena); $\mathrm{SBiH}$ - Stranka za BiH; SBB - Savez za bolju budućnost BiH; DF - Demokratska fronta.
} 
42 poslanců, z nichž je 28 voleno na území FBIH a 14 na území RS. ${ }^{31}$ Pro volby v r. 1996 byl poměrný systém reformován v několika oblastech (velikost shromáždění, počet a velikost obvodů, další přerozdělovánî).

V reakci na problémy vyvstavší ve volbách chtěla mezinárodní správa země v čele s Vysokým komisařem před dalšími volbami v roce 1998 oslabit etnické rozdělení země (Fink-Hafner, Lajh a Krašovec 2011: 19), upřednostnit umírněné strany na úkor stran vyhraněně nacionalistických (Manning 2004: 69) a posílit vazby mezi konkrétními politiky a jejich voliči (Hareovu kvótu nahradil dělitel SaintLaguë). Cílem další reformy před volbami 2000 bylo posílit geografickou reprezentativitu a vazby poslanců a voličů, proporcionalitu výstupů systému, reprezentaci co nejvíce proudů společnosti a oslabit největší nacionalistické strany. Ve skutečnosti ale změny (více volebních obvodů, kompenzační mandáty) měly jen malý vliv na posílení mezietnických apelů, konsensuálních kandidátů a mezietnických stran. Naopak zvýšily fragmentaci stranického systému, ztížily formování vlád a efektivitu vládnutí (Belloni 2004: 341-342, 349). ${ }^{32}$ Sf cílem alespoň částečně zmenšit fragmentaci stranického systému došlo k dalším reformám pro volby 2002 (klauzule v obvodech) a 2006 (omezení postupu do druhého skrutinia).

\section{d. Svazová republika Jugoslávie / Srbsko a Černá Hora}

Jugoslávský systém byl až do přelomu století polosoutěživý, přičemž predominantními stranami byla v Srbsku Miloševićova SPS a v Černé Hoře do r. 1997 DPS CG CG $^{33}$ čele Milo Đukanovićem a Momirem Bulatovićem (po jejich rozkolu došlo ke zvýšení soutěživosti).

Pro volby do Rady občanů byl v r. 1992 zaveden smíšený volební systém s převahou poměrně složky nad jednokolovou většinovou. Přímo v ústavě SRJ (přijata 1992) navíc bylo zakotveno, že jeden poslanec Rady občanů připadal na 65000 voličů, přičemž žádná z republik neměla mít $\mathrm{v}$ této komoře méně než 30 poslanců. Podle dostupných údajů ale nebyl volební systém pro tyto volby přijat demokraticky (Kasapović 2010d: 1705). Reformy volebního systému obecně byly využíány Slobodanem Miloševićem a jeho SPS a spojeneckou DPS CG (později SNP CG) k zajištění vlastní dominance v parlamentu.

Na přelomu let 1992 a 1993 došlo k zavedení poměrného listinného systému. Tato reforma byla na rozdíl od předchozí diskutována s opozicí (Kasapović 2010d: 1704). Hlavní motivací byla nízká legitimita plynoucí z prvních př́mých voleb

\footnotetext{
31 Volební systém ani období nejsou v ústavě přímo uvedeny. Daytonská dohoda ale umožňovala zkrácení prvních (třî) volebních období na dva roky.

32 Potenciální směr působení reformy je obtížné určit, protože reformou došlo sice ke zmenšení velikosti obvodů, ale zároveň bylo zavedeno další kolo přerozdělení zbývajících mandátů na základě celkových hlasů (pro účely klasifikace ale zařazeno spíše do inkluzivního směru) (Šedo 2007: 62-63). 33 DPS CG - Demokratska partija socijalista Crne Gore (dřive SK CG); SNP CG - Socijalistička narodna partija Crne Gore.
} 
téhož roku, které bojkotovala srbská i černohorská demokratická opozice. SPS (v Srbsku získala 69 \% mandátů, 54 \% celkově) a DPS CG (v Černé Hoře 77 \%, 17 \% celkově) proto přistoupily při jednání s opozicí na reformu volebního systému a na vyspání předčasných voleb (Sekelj 2000: 60-61). Další dvě reformy se týkaly počtu a velikosti obvodů: konkrétně pro volby 1996 došlo k vysokému navýšení počtu obvodů a pro volby 2000 naopak k mírnému snížení počtu obvodů. ${ }^{34,35}$

\section{e. Srbsko}

Srbský stranický systém lze charakterizovat jako atomizovaný multipartismus, respektive jako polarizovaný pluralismus s multipolární strukturou. Rozhodujícím faktorem orientace voličů jsou vůdčí politici jednotlivých stran (srov. Bochsler 2010: 103-104; Kasapović 2010d: 1704). Mezi nejvýznamnější strany patří konzervativní SNS Tomislava Nikoliće a Aleksandara Vučiće, socialistická SPS dříve Slobodana Miliševiće a poté Ivici Dačiće, středolevicová DS původně pod vedením Borise Tadiće, který následně založil SDS. Mezi výraznější strany dříve patřila také středopravicová DSS Vojislava Koštunici a liberálně-konzervativní G17 plus Mlađana Dinkiće. ${ }^{36}$ Druhdy významnější pozici zastávaly komunistická JUL Miloševićovy manželky Mirjany Marković, monarchistické a konzervativní SPO Vuka Draškoviće a radikálně nacionalistická SRS Vojislava Šešelje. Až do r. 2000 byl srbský systém polosoutěživý, kdy predominantní stranou byla SPS podporovaná JUL a SRS. Téměř všechny strany kandidují v širokých koalicích, v nichž ale mají výsadní pozici výše uvedené strany a jejich lídři (srov. Bochsler 2010: 99-117; Kasapović 2010d: 1704; Cabada 2004a: 172-174; Balík 2002: 402). ${ }^{37}$

Pro volby 1990 byl dvoukolový většinový systém s uzavřeným druhým kolem vybrán vládnoucími (post)komunisty v čele se Slobodanem Miloševićem (FinkHafner, Lajh a Krašovec 2011: 18). Většinový systém skutečně zvýhodnil vládnoucí SPS, protože ovládala ústřední média a měla vybudovanou infrastrukturu (Tejchman a Pelikán 2013: 509-510). Př́mo v ústavě (schválena 1990, nahrazena 2006) je zakotveno, že se Národní skupština skládá z 250 poslanců.

Přes výsadní pozici Slobodana Miloševiće a SPS (78 \% mandátů) došlo od voleb v roce $1992 \mathrm{k}$ zavedení poměrného listinného volebního systému na základě dohody SPS s opozicí u kulatého stolu (Fink-Hafner, Lajh a Krašovec 2011: 18).

\footnotetext{
${ }^{34}$ Bližší informace o pozadí těchto dvou reforem nejsou bohužel dostupné.

35 Podle ústavní listiny (přijata 2003) se Skupština SCG skládala z 91 poslanců ze Srbska a 35 z Černé Hory volených prímo. Během prvních dvou let ale měli být poslanci voleni nepřímo (delegováni) parlamenty obou entit. Vzhledem k osamostatnění Černé Hory ale k př́mým volbám do Skupštiny SCG již nedošlo.

${ }^{36}$ Všechny strany veřejně vystupují proti samostatné státnosti Kosova, nicméně v r. 2013 došlo k podepsání Bruselské dohody, která pod dohledem EU usiluje o stabilizaci vztahů Srbska a Kosova.

${ }^{37}$ SNS - Srpska napredna stranka; DS - Demokratska stranka; SDS - Socijaldemokratska stranka (dříve: NDS - Nova demokratska stranka); DSS - Demokratska stranka Srbije; JUL - Jugoslovenska levica; SPO Srpski pokret obnove; SRS - Srpska radikalna stranka.
} 
s cílem znesnadnit pozici opozice došlo pro volby 1997 ke zvýšení počtu volebních obvodů (Šedo 2007: 68). Na základě širokého konsensu politických aktérů v souvislosti s pádem Miloševićova režimu byl v r. 2000 zaveden jeden celostátní obvod. Mimo jiné $\mathrm{v}$ důsledku mezinárodního tlaku během období, kdy se vyskytovalo množství menšinově definovaných konfliktů a kdy $\mathrm{v}$ předešlých volbách koalice menšinových stran nepřekročila $5 \%$ klauzuli, přibylo do ústavy z r.2006 ustanovení o zajištění rovnosti členů různých národnostních menšin (Bochsler 2008: 161; Bochsler 2010: 102). v návaznosti na to byla zrušena aplikace uzavírací klauzule pro politické strany menšin.

\section{f. Černá Hora}

Stranický systém v Černé Hoře lze charakterizovat jako extrémní multipartismus, respektive jako dostředivý pluralismus. Důležitým faktorem orientace voličů jsou vůdčí politici jednotlivých stran. Predominantní stranou je DPS CG Milo Đukanoviće, která zvítězila ve všech volbách a účastnila se všech vlád. Před rozchodem Milo Đukanoviće a Momira Bulatoviće v r. 1997 měla DPS CG v polosoutěživém systému výsadní postavení. Poté došlo k oddělení levicovější a prosrbské SNP CG Momira Bulatovice a zvýšení soutěživosti. DPS CG se následně vyprofilovala jako proevropská strana. Tyto dvě strany zůstaly nejvýznamnějšími, přičemž $\mathrm{k}$ dalším významným stranám patři prosrbská konzervativní NOVA, sociálnědemokratická SDP CG a dříve liberální pročernohorská LS CG a konzervativní prosrbská NS CG. Strany často kandidují v koalicích sdružených kolem výše uvedených stran a jejich lídrů (srov. Bieber 2010: 129; Vuković 2010: 61; Komar a Vujović 2007: 55; Gallenkamp a Stöver 2010: 1365; Strmiska 2000; Strmiska 2001). ${ }^{38}$

O designu poměrného volebního systému do černohorské Skupštiny pro volby 1990 se rozhodlo na fóru politických aktérů v první polovině roku 1990, kde byly zastoupeny všechny relevantní politické skupiny, což následně přispělo k téměř všeobecné podpoře zavedeného systému (Pavićević et al. 2007: 14).

Dominantní pozice ale umožňovala DPS CG účelově měnit volební design a svoji pozici tak posilovat (Bieber 2003: 28; Strmiska 2000; Komar a Vujović 2007: 54). Volební inženýrství bylo využito v období jejího spojenectví se srbskou SPS a týkalo se především účelových změn hranic a počtu volebních obvodů (FinkHafner, Lajh a Krašovec 2011: 18). V př́padě voleb 1992 ale šlo o vstřícný krok DPS směrem k opozici (zaveden jeden obvod) (Pavićević et al. 2007: 86). Př́mo v ústavě (schválena 1992) bylo zakotveno, že jeden poslanec připadá na 6000 voličů. DPS CG před volbami 1996 zavedla opět více volebních obvodů. Přestože reforma byla formálně zdůvodněna vstřícností $\mathrm{k}$ muslimské a albánské menšině, jejím prostřednictvím si DPS CG chtěla zajistit co nejlepší výsledek (Vojtěchovský

${ }^{38}$ NOVA - Nova srpska demokratka (dřive: SL - Srpska lista); SDP CG - Socijaldemokratska partija Crne Gore; LS CG - Liberalni savez Crne Gore; NS CG - Narodna stranka Crne Gore. 
2016: 191; Pavićević et al. 2007: 86). Pro volby 1998 byl znovu zaveden jeden celostátní obvod, který ale byl doplněn speciálním obvodem pro albánskou menšinu (a snížením uzavírací klauzule). PS CG k reformě přikročila poté, co se od ní oddělila SNP CG, ve snaze zajistit si podporu černohorských menšin, respektive Albánců (Morrison 2009: 124-125; Džankić 2012: 46). Ve volbách v období 20012006 docházelo pouze k automatickým změnám velikosti Skupštiny.

V rámci přijetí nové ústavy bylo v roce 2007 upuštěno od plovoucího počtu poslanců a př́mo do ústavy byl zanesen fixní počet 81 poslanců. Zároveň bylo v ústavě zakotveno právo menšin na ,autentickou reprezentaci“ ${ }^{39}$ Po přijetí ústavy byla několik let diskutována ústavní konformnost speciálního obvodu pouze pro albánskou menšinu (mj. početnějši menšinou než Albánci jsou Bosňáci a Muslimové). $v$ důsledku toho byl (i za přispění nátlaku evropských institucí) v r. 2011 zrušen albánský obvod a všechny mandáty se nyní rozdělují v jednom obvodu (Džankić 2012: 45-47). Uzavírací klauzule ve výši $3 \%$ je sice stále aplikována na celostátní úrovni, ale pokud žádná z albánských stran uzavírací klauzuli nepřekročí, jsou tři mandáty rozděleny mezi strany menšin, které překročí alespoň $0,7 \%$ hlasů. Zároveň pokud žádná z chorvatských stran nepřekročí $0,7 \%$ hlasů, ale dosáhne alespoň $0,35 \%$ hlasů, má nárok na jeden mandát.

\section{g. Kosovo}

Stranický systém v Kosovu lze charakterizovat jako extrémní multipartismus, respektive jako dostredivý pluralismus. Dvěma největšími stranami jsou konzervativnější a vyhraněnější PDK a liberálnější a umírněnější LDK. Mezi další významnější strany patři konzervativní $A A K$, radikální VV a liberální $A K R$. Všechny strany podporují samostatnost Kosova a ve volbách většinou kandidují samostatně (srov. Stojarová 2010: 151-166). ${ }^{40}$

Poměrný listinný volební systém v Kosovu byl zaveden v rámci Dočasné administrativní mise OSN v Kosovu (Stojarová 2010: 151) a též prostřednictvím OSCE a její mise v Kosovu. Hlavním cílem designu volebního systému pruitom měla být adekvátní reprezentativnost menšin a transparentnost (Taylor 2005: 436, 445-447). Přímo součástí ústavy (schválena 2008) je, že Shromáždění Kosova se skládá ze 120 poslanců (z nichž je 20 mandátů garantováno zástupcům menšin, z toho minimálně deset mandátů je určeno srbským zástupcům; tři bosňáckým; dva tureckým; po jednom romským; goranským; aškalským; egyptským; jeden romským, aškalským nebo egyptským s nejvyšším podílem hlasů).

Cílem reformy před volbami v r. 2007 bylo stabilizovat systém a snížit počet stran v parlamentu. Proto byla na celostátní úrovni stanovena uzavírací klauzule,

\footnotetext{
${ }^{39}$ Podrobnosti o důvodu stanovení fixní velikosti Skupštiny nejsou bohužel známy.

40 PDK - Partia Demokratike e Kosovës/Demokratická strana Kosova; LDK - Lidhja Demokratike e Kosovës/Demokratická liga Kosova; AAK - Aleanca për Ardhmërinë e Kosovës/Aliance pro budoucnost Kosova; VV - Vetëvendosje/Sebeurčení; AKR - Aleanca Kosova e Re/Nová aliance Kosova.
} 
která se ale netýká stran národnostních menšin (zároveň změněn typ kandidátních listin). Reformu provedly politické strany mimom jiné na nátlak obyvatel (především v otázce kandidátních listin) (Mjekiqi a Gallagher 2015: 106-107).

\section{h. Makedonie}

Makedonský stranický systém lze charakterizovat jako omezený multipartismus, respektive jako umírněný pluralismus s dvojitou bipolární strukturou. Nejsilnějšími makedonskými stranami jsou levicový SDSM a pravicová VMRO-DPMNE. $\mathrm{v}$ rámci albánských stran jsou nejsilnějšími stranami radikálnější DUI a umírněnější DPA. Nejsilnější albánskou stranou dříve byla pravicová PDP. Především makedonské strany přitom často kandidují v rámci koalic s SDSM a VMRODPMNE (srov. Šedo 2010c: 165-179; Kasapović 2010c: 1272; Rosůlek 2008a: 7273; Rosůlek 2008b: 350; Strmiska 1999).41

Pro volby do makedonského Shromáždění v r. 1990 byl vybrán dvoukolový většinový volební systém s polozavřeným druhým kolem. O volebním designu se přitom poprvé jednalo v srpnu 1990 a mohli se k němu vyjádřit i představitelé vznikajících stran, kteří nebyli poslanci (Rychlík a Kouba 2003: 250). Přímo v ústavě (schválena 1991, podstatné revize 2001 v rámci Ohridské rámcové dohody) je zakotveno, že se Shromáždění skládá nejméně ze 120 a nejvíce ze 140 poslanců.

Po čtyřleté diskuzi mezi SDSM a VMRO-DPMNE bylo před volbami 1998 schváleno zavedení paralelního smíšeného volebního systému (většina mandátů rozdělována modifikovaným dvoukolovým systémem s uzavřeným druhým kolem ${ }^{42}$ a zbytek poměrným listinným systémem). Koalici v čele se SDSM přitom v Shromáždění náleželo $73 \%$ mandátů (VMRO-DPMNE volby v roce 1994 bojkotovala z obavy z možných manipulacî). Systém ale byl zároveň kritizován makedonskými Albánci kvůli zavedení uzavírací klauzule (Szajkowski 1999 59-60; Cabada 2004b: 247).

V návaznosti na Ohridskou rámcovou dohodu (podepsána prezidentem a zástupci VMRO-DPMNE, SDSM, DPA, PDP, USA a EU) byl pro volby 2002 zaveden poměrný listinný systém. Albánské strany přitom chtěly čistý poměrný systém s jedním obvodem, naopak makedonské strany si přály rozdělení do malých obvodů. Nakonec byl schválen kompromisní návrh (šest dvacetimandátových obvodů, z nich dva s početní převahou Albánců) (Rosůlek 2008b: 347; Birch 2003: 44)

Před volbami v r. 2011, kdy opozice v čele se SDSM zasedání parlamentu bojkotovala, zvětšila vládnoucí VMRO-DPMNE velikost Shromáždění o další tři

41 SDSM - Socijaldemokratski sojuz na Makedonija (dř́ve: SKM-PDP - Sojuz na komunistite na Makedonija - Partija za demokratska preobraz̧ba); DUI - Demokratska unija za integracija; DPA Demokratska partija na Albancite; PDP - Partija za demokratski prosperite.

42 Podmínkou pro obdržení mandátu v prvním kole byl zisk hlasů alespoň jedné třetiny všech registrovaných voličů. 
mandáty pro makedonskou diasporu (Berisha 2016: 11-12). VMRO-DPMNE při reformě (správně) předpokládala, že většina makedonských emigrantů je pravicově orientována a bude volit právě ji (Rychlík 2016b: 366). Přestože mají být tyto mandáty obsazovány poměrným systémem, jsou fakticky obsazovány prostřednictvím jednokolového většinového systému.

\section{Komparace volebního designu, reforem a inženýrství}

Všechny ústavy postjugoslávských entit jsou psané a rigidní, přičemž je potřeba dvoutřetinových většin všech poslanců (popř́padě dalších podmínek) k jejich změně. Typ volebního systému je ale $\mathrm{v}$ ústavním textu uveden prrímo pouze od r. 2000 ve Slovinsku a od r. 2008 v Kosovu. Z dalších zkoumaných parametrů je pak v ústavách uvedena velikost hlavní komory ve Slovinsku, Bosně a Hercegovině, SRJ, Srbsku, Černé Hoře (od 2007), Kosovu a ve formě intervalu také v Chorvatsku, Černé Hoře (do 2007) a Makedonii. Uzavírací klauzule je pak uvedena pouze v ústavě Slovinska. Ostatní parametry nejsou součástí žádného ústavního textu.

K reformě volebního zákona je dvoutřetinová většina všech poslanců vyžadována ve Slovinsku a dř́ive SRJ. v Chorvatsku, Srbsku, Černé Hoře a Makedonii $\mathrm{k}$ reformě volebního systému postačuje pouze nadpoloviční většina všech poslanců hlavní komory, doplněná v př́ípadě Bosny a Hercegoviny ${ }^{43}$ a SCG ${ }^{44}$ o další podmínky. v Kosovu stačí ke změně volebního designu nadpoloviční většina přítomných poslanců (poměrný systém je ale uveden přímo v ústavě).

Rigidní volební design se vyskytuje v polovině př́padů - ve Slovinsku, Kosovu, SRJ a také Bosně a Hercegovině (kde jsou změny politického a volebního systému omezeny splněním dalších podmínek). Naopak flexibilní volební design lze najít ve druhé polovině př́padů, tedy v Chorvatsku, Srbsku, Černé Hoře a Makedonii. Flexibilní volební design zásadně usnadňuje vládním aktérům disponujícím nadpoloviční většinou mandátů činit volební reformy a využívat nástroje volebního inženýrství. Naproti tomu rigidní design je pro volební inženýrství potenciální překážkou (viz Tabulka č. 1).

\footnotetext{
${ }^{43}$ Ke změně volebního designu je vyžadován souhlas nadpoloviční většiny hlasujících poslanců každé z komor. Nadto je u obou procedur vyžadován souhlas alespoň jedné třetiny poslanců každé z entit. Pokud ke splnění této podmínky nedojde, je ustavena speciální komise. V př́padě, že ani jí se nepodaří získat požadovaného podílu zástupců, je návrh schvalován většinou hlasujících, ale jen pokud se proti zákonu nevysloví dvě třetiny zástupců nějaké entity. Navíc, pokud je rozhodnutí označeno jako ohrožující životní zájmy Bosňáků, Chorvatů nebo Srbů většinou př́slušných delegátů, tak musí být návrh schválen většinou hlasujících delegátů z každé entity.

${ }^{44}$ Ke změně ústavy i volebního zákona do hlavní komory SRJ byl vyžadován souhlas dvou třetin všech poslanců každé z komor a po r. 2003 souhlas nadpoloviční většiny všech poslanců a nadpoloviční většiny všech hlasů poslanců každé z republik.
} 
Tabulka č. 1

\begin{tabular}{|c|c|c|c|c|c|c|c|c|c|c|c|}
\hline \multicolumn{12}{|c|}{ Právní limity } \\
\hline 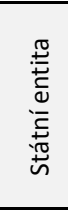 & 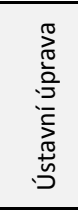 & Komora parlamentu & $\begin{array}{l}\geq \\
0 \\
\frac{1}{0} \\
0 \\
\stackrel{2}{2}\end{array}$ & 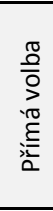 & 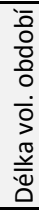 & 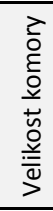 & 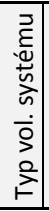 & 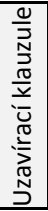 & $\begin{array}{c}\text { Většina nutná } \\
\text { pro změnu } \\
\text { ústavy }\end{array}$ & $\begin{array}{c}\text { Většina } \\
\text { nutná pro } \\
\text { změnu } \\
\text { volebního } \\
\text { zákona do hl. } \\
\text { komory }\end{array}$ & $\begin{array}{c}\text { Typ } \\
\text { volebního } \\
\text { designu }\end{array}$ \\
\hline \multirow{4}{*}{ SLO } & \multirow{2}{*}{1991} & Státní sbor & $\mathrm{D}$ & 1 & 1 & 1 & 0 & 0 & $2 / 3$ všech & $2 / 3$ všech & \multirow{4}{*}{ rigidní } \\
\hline & & Státní rada & $\mathrm{H}$ & 0 & 1 & 1 & 0 & 0 & $x$ & $x$ & \\
\hline & \multirow{2}{*}{2000} & Státní sbor & D & 1 & 1 & 1 & 1 & 1 & $2 / 3$ všech & $2 / 3$ všech & \\
\hline & & Státní rada & $\mathrm{H}$ & 0 & 1 & 1 & 0 & 0 & $x$ & $x$ & \\
\hline \multirow{6}{*}{$\mathrm{HR}$} & \multirow{2}{*}{1990} & Poslanecká sněmovna & $\mathrm{D}$ & 1 & 1 & 0,5 & 0 & 0 & $2 / 3$ všech & $1 / 2$ všech & \multirow{6}{*}{ flexibilní } \\
\hline & & Županská sněmovna & $\mathrm{H}$ & 0,5 & 1 & 0,5 & 0 & 0 & 1/2 prítom. & $1 / 2$ př́tom. & \\
\hline & \multirow{2}{*}{2000} & Poslanecká sněmovna & $\mathrm{D}$ & 1 & 1 & 0,5 & 0 & 0 & $2 / 3$ všech & $1 / 2$ všech & \\
\hline & & Županská sněmovna & $\mathrm{H}$ & 0 & 1 & 1 & 0 & 0 & 1/2 prítom. & 1/2 př́tom. & \\
\hline & 2001 & Chorvatský sabor & 1 & 1 & 1 & 0,5 & 0 & 0 & $2 / 3$ všech & $1 / 2$ všech & \\
\hline & 2010 & Chorvatský sabor & 1 & 1 & 1 & 0,5 & 0 & 0 & $2 / 3$ všech & $1 / 2$ všech & \\
\hline \multirow{2}{*}{$\mathrm{BiH}$} & \multirow{2}{*}{1995} & Poslanecká sněmovna & $\mathrm{D}$ & 1 & 0 & 1 & 0 & 0 & 2/3 prítom.+ & 1/2 prítom.+ & \multirow{2}{*}{ rigidní } \\
\hline & & Sněmovna národů & $\mathrm{H}$ & 0 & 0 & 1 & 0 & 0 & $2 / 3$ prítom.+ & 1/2 př́tom.+ & \\
\hline \multirow{2}{*}{ SRJ } & \multirow{2}{*}{1992} & Rada občanů & $\mathrm{D}$ & 1 & 1 & 0,5 & 0 & 0 & $2 / 3$ všech+ & $2 / 3$ všech & \multirow{2}{*}{ rigidní } \\
\hline & & Rada republik & $\mathrm{H}$ & 1 & 1 & 1 & 0 & 0 & $2 / 3$ všech+ & $2 / 3$ všech & \\
\hline SGC & 2003 & Skupština & 1 & 0,5 & 1 & 1 & 0 & 0 & $1 / 2$ všech+ & $1 / 2$ všech+ & flexibilní \\
\hline \multirow{2}{*}{ SRB } & 1990 & Národní skupština & 1 & 1 & 1 & 1 & 0 & 0 & $2 / 3$ všech+ref. & $1 / 2$ všech & \multirow{2}{*}{ flexibilní } \\
\hline & 2006 & Národní skupština & 1 & 1 & 1 & 1 & 0 & 0 & $2 / 3$ všech+ref. & $1 / 2$ všech & \\
\hline \multirow{2}{*}{ MNE } & 1992 & Skupština & 1 & 1 & 1 & 0,5 & 0 & 0 & $2 / 3$ všech & $1 / 2$ všech & \multirow{2}{*}{ flexibilní } \\
\hline & 2007 & Skupština & 1 & 1 & 1 & 1 & 0 & 0 & $2 / 3$ všech & $1 / 2$ všech & \\
\hline RKS & 2008 & Shromáždění & 1 & 1 & 1 & 1 & 1 & 0 & $2 / 3$ všech & 1/2 př́tom. & rigidní \\
\hline MK & 1991 & Shromáždění & 1 & 1 & 1 & 0,5 & 0 & 0 & $2 / 3$ všech & $1 / 2$ všech & flexibilní \\
\hline
\end{tabular}

1 značí přítomnost nebo naplnění kritéria $v$ textu ústavy; 0,5 značí neabsolutně definovanou prítomnost nebo částečné naplnění kritéria v textu ústavy; 0 značí absenci nebo negaci kritéria v textu ústavy; $D$ značí dolní komoru; H značí horní komoru; + značí přítomnost dalších podmínek

Zdroj: Autor

V prvních prímých volbách (viz Tabulka č. 2), které se v původních republikách SFRJ uskutečnily v roce 1990, v SRJ v r. 1992 a v Kosovu v r. 2001, byl vybrán v polovině př́padů poměrný volební systém (Slovinsko, BiH, Černá Hora, Kosovo), ve čtvrtině př́padů dvoukolový většinový systém s polouzavřeným druhým kolem (Chorvatsko, Makedonie), v jednom prŕpadu dvoukolový většinový systém s uzavřeným druhým kolem (Srbsko) a v jednom případu smíšený paralelní systém (SRJ).

Pokud by bylo zavedení volebního designu pro první přímé volby považováno za reformu, tak by se podle Katzovy klasifikace jednalo ve všech př́padech o velké reformy, protože došlo ke změně typu volebního systému. Podle Shugartovy 
klasifikace by pak šlo reformy (zavedenî) klasifikovat za reformy pro výsledek reformy v potenciálně inkluzivním směru. Cílem totiž bylo otevření politického systému nevládnoucím aktérům a umožnění politické soutěže. ${ }^{45}$

Tabulka č. 2

\begin{tabular}{|c|c|c|c|c|c|c|c|c|}
\hline \multicolumn{9}{|c|}{ První přímé volby } \\
\hline $\begin{array}{l}\text { Státní } \\
\text { entita }\end{array}$ & SLO & $\mathrm{HR}$ & $\mathrm{BiH}$ & SRB & MNE & MK & SRJ & RKS \\
\hline Rok voleb & 1990 & 1990 & 1990 & 1990 & 1990 & 1990 & 1992 & 2001 \\
\hline $\begin{array}{l}\text { Volební } \\
\text { systém }\end{array}$ & PR list & TRS-MPS & PR list & TRS-MS & PR list & TRS-MPS & Mixed & PR list \\
\hline $\begin{array}{c}\text { Reforma } \\
\text { pro }\end{array}$ & \multicolumn{8}{|c|}{ výsledek reformy } \\
\hline Směr & \multicolumn{8}{|c|}{ inkluzivní } \\
\hline $\begin{array}{l}\text { Hlavní } \\
\text { aktéři }\end{array}$ & $\begin{array}{l}\text { politici: } \\
\text { vláda } \\
\text { a mimop } \\
\text { arl. }\end{array}$ & $\begin{array}{l}\text { politici: } \\
\text { vláda }\end{array}$ & politici & politici & $\begin{array}{c}\text { politici: } \\
\text { vláda } \\
\text { a mimoparl } \\
.\end{array}$ & $\begin{array}{l}\text { politici: } \\
\text { vláda } \\
\text { a mimop } \\
\text { arl. }\end{array}$ & $\begin{array}{l}\text { politici: } \\
\text { vláda }\end{array}$ & $\begin{array}{l}\text { externí } \\
\text { aktéři }\end{array}$ \\
\hline $\begin{array}{l}\text { Typ } \\
\text { reformy }\end{array}$ & $\begin{array}{l}\text { dohoda } \\
\text { pol. elit }\end{array}$ & $\begin{array}{l}\text { vnucení } \\
\text { vládní } \\
\text { většinou }\end{array}$ & N/A & $\begin{array}{l}\text { vnucení } \\
\text { vládní } \\
\text { většinou }\end{array}$ & $\begin{array}{l}\text { dohoda } \\
\text { pol. elit }\end{array}$ & $\begin{array}{l}\text { dohoda } \\
\text { pol. elit }\end{array}$ & $\begin{array}{l}\text { vnucení } \\
\text { vládní } \\
\text { většinou }\end{array}$ & $\begin{array}{c}\text { mezinárod } \\
\text { ní org. }\end{array}$ \\
\hline
\end{tabular}

Zdroj: Autor

Z celkových 60 voleb do hlavních komor, které se v postjugoslávském prostoru v letech 1990 až 2015 uskutečnily, proběhlo téměř $90 \%$ (52 voleb, přesně $87 \%$ ) podle poměrného listinného volebního systému (viz Graf č. 1). Podle dvoukolového většinového volebního systému se konaly jen čtvery volby (7\%), přičemž v př́padě Chorvatska a Srbska šlo pouze o první volby a v prŕpadě Makedonie o první dvoje volby. Podle paralelního smíšeného volebního systému proběhly také čtvery volby $(7 \%)$ : v Chorvatsku byl využit ve druhých a třetích volbách, v Makedonii ve třetích a v SRJ v prvních volbách. v postjugoslávské oblasti tak jasně dominuje využití poměrného volebního systému.

V polovině zkoumaných politických systémů, konkrétně ve Slovinsku, Bosně a Hercegovině a Černé Hoře a Kosovu, je poměrný listinný systém využíván již od prvních prímých voleb. Ve čtvrtině prípadů došlo k zavedení poměrného systému ve druhých volbách, konkrétně v Srbsku (po dvou letech od prvních voleb v rámci

${ }^{45} \mathrm{~V}$ Renwickově typologii mělo zavedení volebního designu v postjugoslávských entitách nejblíže $\mathrm{k}$ typu dohody politických elit (vládnoucí aktéŕi zapojují <mimoparlamentní> opozici se společným cílem umožnit nekonfliktní průběh voleb a následné sestavení vlády, respektive demokratizaci) a typu vnucení vládní většinou (vládnoucí aktéŕi nezapojují vůbec nebo minimálně opozici a jejich cílem je uchovat si co nejsilnější pozici). K problematice využití Renwickovy typologie viz dále v pozn. 54 a 55 a též v Závěru. 
většinového systému) a v SRJ (po necelém roce od prvních voleb v rámci smíšeného systému). $\mathrm{v}$ další čtvrtině př́ípadů pak došlo $\mathrm{k}$ zavedení poměrného systému ve čtvrtých volbách, konkrétně v Chorvatsku (po 11 letech, kdy první volby proběhly podle většinového a další dvoje podle smíšeného systému) a v Makedonii (po 13 letech, kdy se první dvoje volby uskutečnily podle většinového systému a třetí podle smíšeného). v žádném ze systémů tedy nedošlo $\mathrm{k}$ přechodu $\mathrm{z}$ poměrného systému na nějaký jiný systém. Pokud nebyl poměrný systém zaveden již od prvních voleb, tak k reformě na poměrný systém došlo nejpozději ve čtvrtých volbách. Lze tedy potvrdit jasný trend širokého využívání poměrných systémů a zároveň přechodů $\mathrm{k}$ těmto systémům. ${ }^{46}$

\section{Graf č. 1}

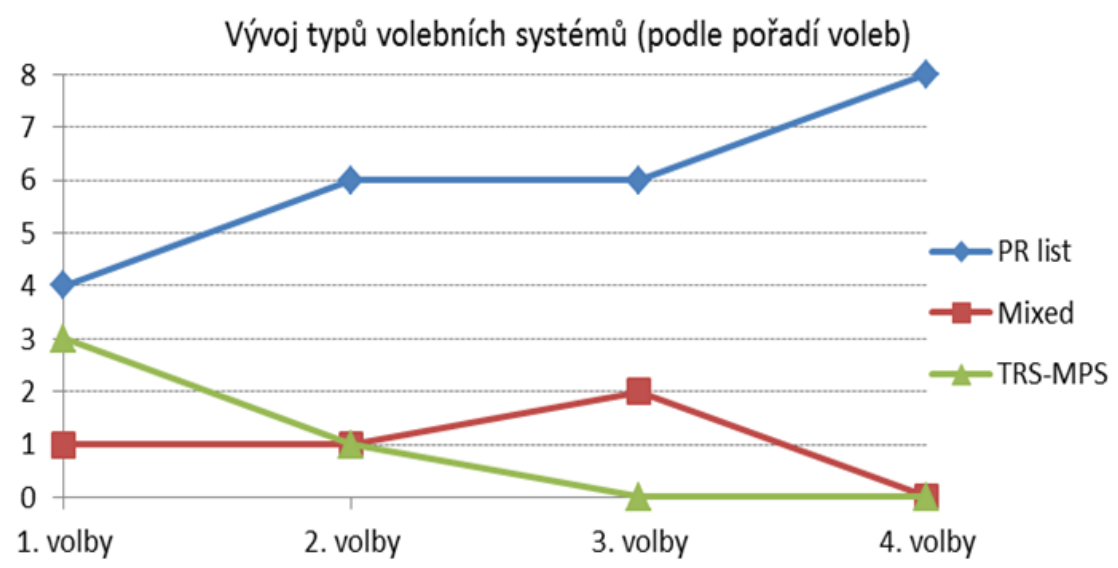

Zdroj: Autor.

V rámci zkoumaného období se uskutečnilo celkem 29 reforem ${ }^{47}$ volebních systémů, což v průměru vychází na 3,6 reformy na každou entitu (viz Graf č. 2). ${ }^{48}$ $\mathrm{Na}$ základě Katzova klasifikačního schématu se jednalo $\mathrm{v}$ pětině případů (6) o velkou reformu, tedy o změnu typu volebního systému, což vychází

\footnotetext{
${ }^{46} \mathrm{~K}$ identifikaci podobných trendů zachovávání či zavádění poměrných systémů již dospěli v širším kontextu např́klad Colomer (2004; 2005: 1-21), Reynolds, Reilly a Ellis (2005: 23-24) ve smyslu směřování většiny volebních reforem $\mathrm{k}$ inkluzivnějším (poměrným nebo smíšeným) volebním systémům, a Nohlen a Kasapović (dle Nohlen 2010: 46-47; 83-84) v kontextu evropských postkomunistických zemí.

47 Respektive 37 reforem, pokud by byl design prvních př́mých voleb považován za reformu (pokud ale není uvedeno jinak, zavedení volebního systému není za reformu v textu považováno).

48 Celkem došlo k 33 změnám zkoumaných parametrů volebních systémů. Ve třech př́padech v Černé Hoře se totiž celková velikost shromáždění odvíjela od počtu obyvatel a v jednom případě se v Chorvatsku velikost obvodu diaspory odvijela od počtu hlasů připadajících na jeden mandát ve standardních obvodech. Vzhledem k automatismu těchto změn je nelze považovat za reformy volebního systému.
} 
v průměru 0,8 velké reformy na každou entitu. Žádná velká reforma ale neproběhla ve Slovinsku, Bosně a Hercegovině, Černé Hoře a Kosovu. v Srbsku a SRJ se uskutečnila jedna velká reforma a v Chorvatsku a Makedonii pak dvě velké reformy. Ve zbývajících čtyřech pětinách (23) případů šlo o malé reformy, tedy i změnu parametrů v rámci již využívaného volebního systému, což vychází v průměru na 2,9 malé reformy na každou entitu. Malé reformy se oproti velkým se ale naopak vyskytly ve všech entitách, přičemž nejvíce se jich uskutečnilo v Černé Hoře a Bosně a Hercegovině, nejméně naopak v Kosovu a Makedonii.

\section{Graf č. 2}

\section{Celkový počet reforem (bez 1. voleb)}

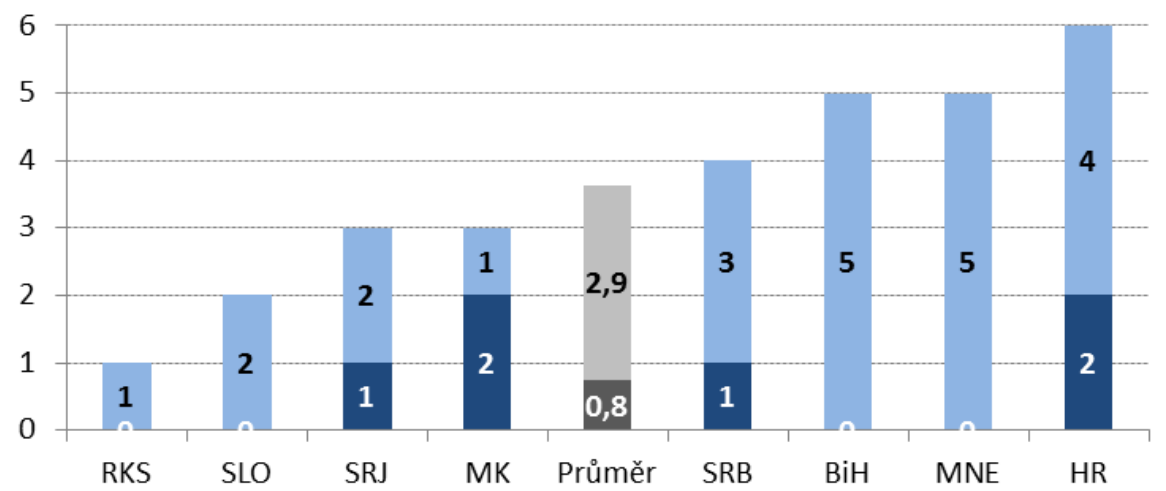

Velké reformy Malé reformy

\section{Zdroj: Autor.}

Ve zkoumaných systémech se volební design vyskytoval beze změny v průměru po dobu 1,8 voleb (viz Graf č. 3 ). ${ }^{49}$ Reforma volebního systému se tedy uskutečnila $\mathrm{v}$ průměru téměr před každými druhými volbami. Z hlediska času pak průměrná doba ${ }^{50}$ využití volebního designu beze změny dosahuje 4,7 roku (viz Graf č. 4). Jinak řečeno, reforma volebního systému se v průměru uskutečnila v o něco delším intervalu, než činí jedno standardní čtyřleté volební obdobíi. ${ }^{51}$ Obecně lze tedy konstatovat, že volební design je $\mathrm{v}$ postjugoslávském prostoru značně nestabilní a dochází $\mathrm{k}$ velmi častým volebním reformám. Mezi jednotlivými systémy

\footnotetext{
49 Zde i dále se jedná o vážené průměry.

${ }^{50}$ Jde o průměr vážený trváním jednotlivých politických systémů, respektive dobou od prvních do posledních voleb.

${ }^{51} \mathrm{~V}$ oblasti totiž dochází $\mathrm{k}$ předčasným volbám (v průměru se volby uskutečňují každého 2,9 roku). Navíc ve čtyřech původních republikách SFRJ došlo k druhým volbám již po dvou letech v roce 1992 (pouze v Makedonii se volby uskutečnily až v r. 1994 a v BiH v důsledku válečného konfliktu až v r. 1996).
} 
samozřejmě existují značné rozdíly. Nejstabilnější volební design se vyskytuje ve Slovinsku a Kosovu, naopak nejméně stabilní v SRJ a Chorvatsku.

Graf č. 3

Průměrný počet voleb s využitím stejného volebního designu

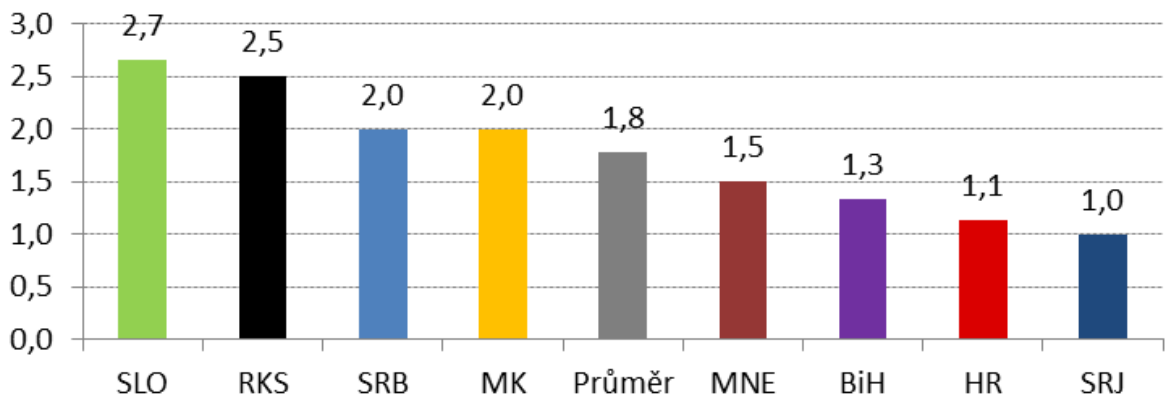

Zdroj: Autor

Graf č. 4

Průměrný počet let s využitím stejného volebního designu

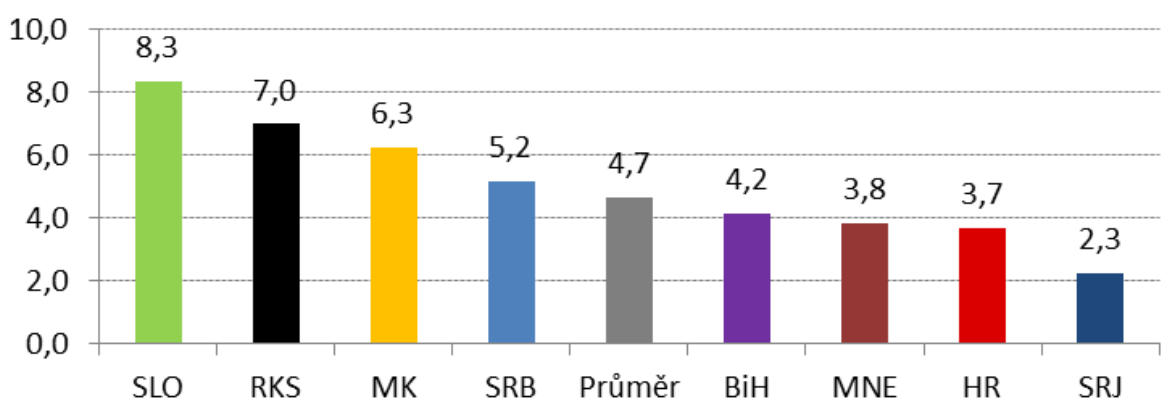

Zdroj: Autor

Velkých reforem se za sledované období uskutečnilo celkem šest ve čtyřech politických systémech, konkrétně v Chorvatsku pro volby 1992 a 2000, v Srbsku a SRJ 1992 (volby 1992/1993) a v Makedonii 1998 a 2002 (viz Tabulka č. 3). $v$ prŕpadě Chorvatska a Makedonie byla nejprve provedena reforma $z$ většinového systému na smíšený a poté reforma na poměrný systém. v př́padě SRJ a Srbska ale rovnou došlo k reformě z většinového na poměrný systém.

Volební design byl kromě SRJ ve všech př́padech velkých reforem flexibilního typu; $\mathrm{k}$ reformě volebního systému tedy postačovala nadpoloviční většina hlasů 
všech poslanců, což umožnilo poměrně hladké prosazení volebních reforem. ${ }^{52} \mathrm{Ve}$ SRJ byl sice volební design rigidního typu (nutný souhlas dvou třetin poslanců obou komor), ale $\mathrm{z}$ důvodu bojkotu předešlých voleb opozicí nebylo rovněž obtížné reformu prosadit.

Tabulka č. 3

\begin{tabular}{|c|c|c|c|c|c|c|}
\hline \multicolumn{7}{|c|}{ Velké reformy } \\
\hline Státní entita & $\mathrm{HR}$ & $\mathrm{HR}$ & SRJ & SRB & MK & MK \\
\hline Rok voleb & 1992 & 2000 & $1992 / 93$ & 1992 & 1998 & 2002 \\
\hline Pořadí voleb & 2. & 4. & 2. & 2. & 3. & 4. \\
\hline Původní VS & TRS-MPS & Mixed & Mixed & TRS-MS & TRS-MPS & Mixed \\
\hline Nový VS & Mixed & PR list & PR list & PR list & Mixed & PR list \\
\hline $\begin{array}{l}\text { Ústavní de- } \\
\text { sign }\end{array}$ & rigidní & rigidní & rigidní & rigidní & rigidní & rigidní \\
\hline $\begin{array}{l}\text { Volební de- } \\
\text { sign }\end{array}$ & flexibilní & flexibilní & rigidní & flexibilní & flexibilní & flexibilní \\
\hline Hlavní aktéři & politici: vláda & $\begin{array}{c}\text { politici: vláda (+opo- } \\
\text { zice) }\end{array}$ & $\begin{array}{l}\text { politici: vláda } \\
\text { (+mimoparla- } \\
\text { mentní), občané }\end{array}$ & $\begin{array}{l}\text { politici: vláda + } \\
\text { opozice, občané }\end{array}$ & $\begin{array}{c}\text { politici: vláda } \\
\text { (+opozice) }\end{array}$ & $\begin{array}{l}\text { politici: vláda } \\
\text { + opozice }\end{array}$ \\
\hline $\begin{array}{l}\text { Důvod re- } \\
\text { formy }\end{array}$ & $\begin{array}{l}\text { posílení pozic } \\
\text { vládnoucích }\end{array}$ & $\begin{array}{l}\text { posílení pozic vlád- } \\
\text { noucích, vzdání se } \\
\text { většinové role }\end{array}$ & $\begin{array}{l}\text { zvýšení legitimity, } \\
\text { zahrnutí opozice } \\
\text { do systému }\end{array}$ & $\begin{array}{c}\text { zvýšení legiti- } \\
\text { mity, zahrnutí } \\
\text { opozice do sys- } \\
\text { tému }\end{array}$ & $\begin{array}{c}\text { zvýšení legiti- } \\
\text { mity, zahrnutí } \\
\text { opozice do sys- } \\
\text { tému }\end{array}$ & $\begin{array}{l}\text { kompromis } \\
\text { po konfliktu }\end{array}$ \\
\hline Směr & inkluzivní & inkluzivní & inkluzivní & inkluzivní & inkluzivní & inkluzivní \\
\hline Reforma pro & reformu & $\begin{array}{c}\text { výsledek reformy/ } \\
\text { reformu }\end{array}$ & výsledek reformy & $\begin{array}{l}\text { výsledek re- } \\
\text { formy }\end{array}$ & $\begin{array}{l}\text { výsledek re- } \\
\text { formy }\end{array}$ & $\begin{array}{l}\text { výsledek re- } \\
\text { formy }\end{array}$ \\
\hline Typ reformy & $\begin{array}{c}\text { vnucení vládní } \\
\text { většinou }\end{array}$ & $\begin{array}{c}\text { vnucení vládní větši- } \\
\text { nou }\end{array}$ & $\begin{array}{c}\text { vyjednávání pol. } \\
\text { elit }\end{array}$ & dohoda pol. elit & dohoda pol. elit & $\begin{array}{c}\text { dohoda pol. } \\
\text { elit }\end{array}$ \\
\hline Demokracie & $\begin{array}{l}\text { nedemokra- } \\
\text { tický }\end{array}$ & demokratizující se & nedemokratický & nedemokratický & nedemokratický & $\begin{array}{c}\text { demokratizu- } \\
\text { jící se }\end{array}$ \\
\hline $\begin{array}{l}\text { Uspořádání } \\
\text { státu }\end{array}$ & unitární & unitární & federativní & $\begin{array}{l}\text { (součást fede- } \\
\text { race) }\end{array}$ & unitární & unitární \\
\hline $\begin{array}{l}\text { Typ pol. sys- } \\
\text { tému }\end{array}$ & $\begin{array}{l}\text { fakticky polo- } \\
\text { prezidentský }\end{array}$ & $\begin{array}{c}\text { fakticky poloprezi- } \\
\text { dentský }\end{array}$ & $\begin{array}{c}\text { fakticky poloprezi- } \\
\text { dentský }\end{array}$ & $\begin{array}{l}\text { fakticky polo- } \\
\text { prezidentský }\end{array}$ & $\begin{array}{c}\text { parlamentní } \\
\text { (silný prezident) }\end{array}$ & parlamentní \\
\hline $\begin{array}{c}\text { Typ stranic- } \\
\text { kého sys- } \\
\text { tému }\end{array}$ & $\begin{array}{l}\text { predominantní } \\
\text { strany }\end{array}$ & $\begin{array}{l}\text { přechod od predo- } \\
\text { minantního sys. } \\
\text { k dostředivému plu- } \\
\text { ralismu s bipolární } \\
\text { strukturou }\end{array}$ & $\begin{array}{l}\text { predominantní } \\
\text { strany }\end{array}$ & $\begin{array}{l}\text { predominantní } \\
\text { strany }\end{array}$ & $\begin{array}{l}\text { umírněný plura- } \\
\text { lismus s dvoji- } \\
\text { tou bipolární } \\
\text { strukturou }\end{array}$ & $\begin{array}{c}\text { umírněný } \\
\text { pluralismus } \\
\text { s dvojitou bi- } \\
\text { polární struk- } \\
\text { turou }\end{array}$ \\
\hline Soutěživost & polosoutěživý & soutěživý & polosoutěživý & polosoutěživý & soutěživý & soutěživý \\
\hline
\end{tabular}

Zdroj: Autor.

K velkým reformám došlo v situacích, kdy demokracie v jednotlivých systémech nebyla konsolidovaná a stabilizovaná. To souviselo s fakticky poloprezidentskými a polosoutěživými režimy Tuđmana a Miloševiće, když demokratizace pokročila až s odchodem těchto politiků v roce 2000. v př́padě Makedonie pak byl systém sice fakticky soutěživý, ale demokracie opět nebyla

${ }^{52} \mathrm{~V}$ ostatních systémech s flexibilním volebním designem ale k velkým reformám nedošlo a zůstal $\mathrm{v}$ nich zaveden poměrný systém. 
konsolidovaná a stabilní. To navíc bylo před volbami 1998 doprovázeno absencí opozice v parlamentu a před volbami 2002 situací po ukončení ozbrojeného konfliktu.

Hlavními aktéry všech velkých reforem byli politici - vládnoucí aktéři, kteří do reformy v různé míre zapojili také opozici, at' už byla součástí parlamentu nebo se z důvodu bojkotu nacházela mimo parlament (SRJ, Makedonie 1998). v prŕpadě Makedonie (2002) pak byl v souvislosti s Ohridskou dohodou vliv patrný také externích aktérů a v SRJ a Srbsku také vliv organizovaných mas občanů.

Navzdory uvedeným charakteristikám jednotlivých politických systémů velké reformy ve všech př́padech směřovaly potenciálně inkluzivním směrem, tedy oproti dříve využitým systémům byl přijat poměrnější design, který by měl vést k otevřenějšímu politickému systému umožňujícímu větší zastoupení opozice a udržitelnost volebního procesu. Hlavním důvody pro príijetí reforem se ale v jednotlivých systémech lišily - od snahy o zvýšení legitimity systému a reprezentativnosti voleb na základě dohody s (mimoparlamentnî) opozicí (Srbsko 1992, SRJ 1992/1993, Makedonie 1998), přes kompromisní dohodu po skončení občanského konfliktu (Makedonie 2002), až po zachování vlastních pozic a oslabení opozice (Chorvatsko 1992, 2000)..$^{53}$

V rámci Shugartovy klasifikace lze jako reformy pro výsledek reformy označit všechny uvedené př́pady kromě chorvatských. v Chorvatsku v roce 1992 šlo o reformu pro reformu s cílem uchovat co nejsilnější pozici HDZ. v r. 2000 lze pak reformu zařadit na pomezí mezi reformu pro reformu a pro výsledek reformy, protože sice byla schválena v podobě návrhu HDZ, ale ten si zároveň mj. reformou přestal nárokovat většinové postavení. ${ }^{54}$

Přestože velké reformy neproběhly v demokratických systémech, tak všechny byly v potenciálně inkluzivním směru a směřovaly $\mathrm{k}$ poměrnějším systémům. Ve většině př́padů nešlo o intencionální volební inženýrství, ale o reformu designu volebních systémů, které se v různé míre účastnila také opozice. Obecně přechody k poměrnému systému souvisely s otevřením politické soutěže, demokratizací a s přechodem od poloprezidentských režimů k parlamentním režimům.

Malé reformy se na rozdíl od velkých uskutečnily ve všech postjugoslávských entitách (viz Graf č. 5). Z celkových 23 se jich nejvíce uskutečnilo v Bosně a Hercegovině a Černé Hoře a naopak nejméně v Kosovu a ve Slovinsku. Ve všech

53 Dieter Nohlen (2010: 45) přichází s tezí, že k fundamentálním změnám volebního systému dochází pouze ve výjimečných historických situacích, jako jsou ústavní krize nebo kolapsy politického systému.

54 Využití Renwickovy typologie (nejen) pro velké reformy se ukázalo jako ne zcela vhodné pro komparativní typ výzkumu tohoto typu a rozsahu. Přestože o zkoumaných velkých reformách je poměrně dostatek informací, tak je jejich přriřazení či alespoň prriblížení k jednotlivým ideálním typům spekulativní a konečné přriřazení arbitrární. Důvodem je mj. i to, že Renwick v otázce koncepce institucí jasněji nedefinuje redistributivnost, respektive účinnost institucí, a v otázce inkluzivity není jasné jeho pojetí opozice (např́klad zda stačí souhlas části opozice, nebo je nutná širší shoda např́ič stranickým systémem). 
př́padech se malé reformy uskutečnily $\mathrm{v}$ poměrných systémech, jedinou výjimkou byla chorvatská reforma v r. 1995, která proběhla v rámci smíšeného systému. Nejčastěji reformovanou proměnou (viz Graf č. 6) byla velikost a počet obvodů. Naopak nejméně často byla měněna podoba hlasování a volební formule.

\section{Graf č. 5}

\section{Malé reformy}

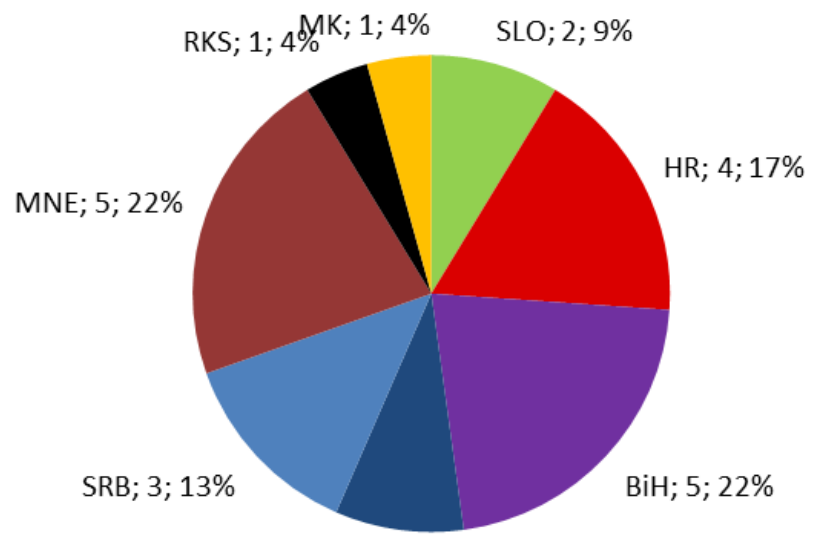

SRJ; $2 ; 9 \%$

Zdroj: Autor.

\section{Graf č. 6}

Zdroj: Autor.

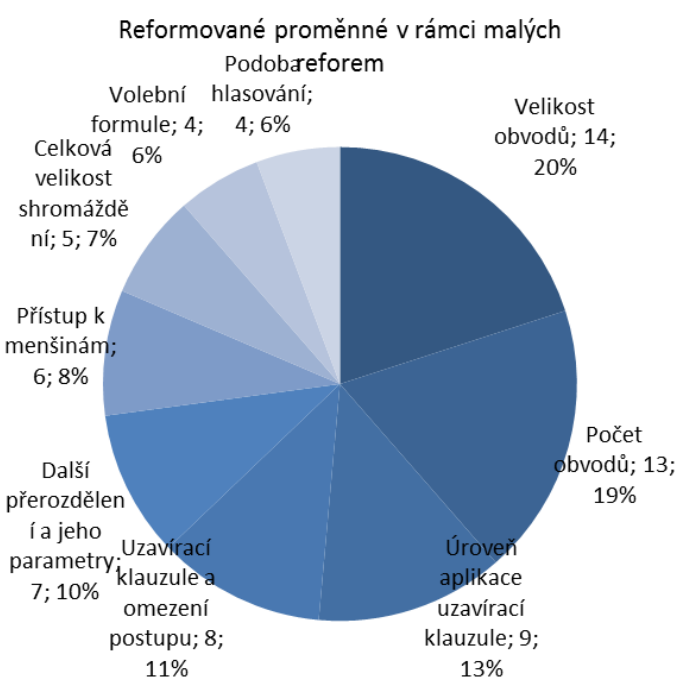


Z hlediska Shugartovy klasifikace lze více než dvě třetiny malých reforem označit za reformy pro výsledek reformy a necelou třetinu za reformy pro reformu (viz Tabulka č. 4). Z hlediska potenciálního směru působení pak necelé dvě třetiny reforem byly spíše $\mathrm{v}$ inkluzivním směru a více než třetina spíše v exkluzivním směru. Malé reformy tedy také povětšinou sloužily $\mathrm{k}$ nápravě dysfunkcí systému, který otvíraly. Zároveň se ale vyskytly př́pady, kdy došlo k intencionálnímu volebnímu inženýrství. ${ }^{55}$

Tabulka č. 4

\begin{tabular}{|c|c|c|c|}
\hline \multicolumn{4}{|c|}{ Malé reformy (a) } \\
\hline \hline & Pro výsledek reformy & Pro reformu & Celkem \\
\hline Inkluzivní & $43 \%$ & $17 \%$ & $60 \%$ \\
\hline Exkluzivní & $26 \%$ & $13 \%$ & $39 \%$ \\
\hline Celkem & $69 \%$ & $30 \%$ & $100 \%$ \\
\hline
\end{tabular}

Zdroj: Autor.

Žádné malé reformy pro reformy se neuskutečnily ve Slovinsku (obě inkluzivní), Bosně a Hercegovině (převaha exkluzivních reforem a snaha o snížení fragmentace stranického systému prostřednictvím zavedení či podpory mezinárodní organizacî) ${ }^{56}$ a Kosovu (jediná exkluzivní reforma - zavedení uzavírací klauzule, neplatící ale pro menšinové strany). $\mathrm{v}$ těchto systémech tedy malé reformy sloužily k nápravě dysfunkcí systému (bez ohledu směr reformy). Naopak pouze malé reformy pro reformy byly provedeny v SRJ (dvě změny počtu a velikosti obvodů za vlády Miloševiće) a Makedonii (vytvoření třech jednomandátových obvodů pro diasporu s cílem posílit VMRO-DPMNE). v těchto systémech tedy došlo $\mathrm{k}$ intencionálnímu volebnímu inženýrství s cílem posílit vládnoucí aktéry (viz Tabulka č. 5).

Ve všech ostatních systémech došlo k využití jak reforem pro reformy, tak i reforem pro výsledky reforem, které ale převažovaly. V Chorvatsku měla reforma (ve smíšeném systému) z r. 1995 prínést benefity HDZ skrze zvýšení podílu mandátů poměrné složky a zavedení dalšího obvodu pro diasporu. Po pádu Tuđmanova režimu byly všechny reformy spíše vinkluzivním směru (počet a definice menšinových mandátů, velikost obvodu diaspory, podoba kandidátní

\footnotetext{
55 Z hlediska Renwickovy typologie je u malých reforem vzhledem k rozdílné míre dostupných informací o jednotlivých reformách ještě obtížnější přiřadit či přiblížit jednotlivé reformy $\mathrm{k}$ ideálním typům, proto není vhodné tuto typologii v této části komparace využít. V tabulce č. 8 (viz Př́lohy) je nicméně alespoň uvedeno, kterému ideálnímu typu reformy se dané reformy nejvíce přibližovaly.

${ }^{56} \mathrm{Na}$ př́kladu BiH se ukazuje, že reformy pro výsledek reformy se nevyskytují jen v potenciálně inkluzivním směru, ale také v exkluzivním (např́iklad když je fragmentace stranického systému vnímána jako problém).
} 
listiny). v Srbsku spočívala reforma pro reformu z r. 1997 v zavedení více menších volebních obvodů s cílem posilit Miloševićovu SPS, což bylo změněno reformou pro výsledek reformy v r. 2000, kdy byl zaveden jeden celostátní obvod. Po pádu Miloševićova režimu pak došlo už jen k reformě pro výsledek reformy spočívající v odstranění uzavírací klauzule pro strany menšin. v Černé Hoře v devadesátých letech došlo ke třem reformám, které týkaly především změny počtu a velikosti obvodů. Konkrétně reformou pro výsledek reformy byl v roce 1992 zaveden jeden obvod, aby byl reformou pro reformu (exkluzivni) v r. 1996 zrušen a o dva roky později (inkluzivně) znovuzaveden (doplněn o obvod pro albánskou menšinu). v novém tisíciletí pak proběhly již jen reformy pro výsledek reformy spíše v inkluzivním směru (celková velikost shromáždění a místo albánského obvodu snížení uzavírací klauzule pro menšinové strany). v těchto systémech se tedy intencionální volební inženýrství vyskytovalo v devadesátých letech a bylo spojeno $\mathrm{s}$ tamějšími nedemokratickými režimy. $\mathrm{v}$ novém tisíciletí se pak vykytovaly pouze reformy pro výsledek reformy s cílem upravit parametry systému považované více méně za dysfunkce.

\section{Tabulka č. 5}

\begin{tabular}{|c|r|r|r|r|r|r|r|r|r|r|}
\hline \multicolumn{10}{|c|}{ Malé reformy (b) } \\
\hline \hline & SLO & HR & BiH & SRJ & SRB & MNE & RKS & MK & \multicolumn{2}{|c|}{ Celkem } \\
\hline Pro výsledek reformy inkluzivnější & 2 & 2 & 2 & 0 & 2 & 2 & 0 & 0 & 10 & $43 \%$ \\
\hline Pro výsledek reformy exkluzivnější & 0 & 1 & 3 & 0 & 0 & 1 & 1 & 0 & 6 & $26 \%$ \\
\hline Pro reformu inkluzivnější & 0 & 1 & 0 & 1 & 0 & 1 & 0 & 1 & 4 & $17 \%$ \\
\hline Pro reformu exkluzivnější & 0 & 0 & 0 & 1 & 1 & 1 & 0 & 0 & 3 & $13 \%$ \\
\hline Celkem & 2 & 4 & 5 & 2 & 3 & 5 & 1 & 1 & 23 & $100 \%$ \\
\hline & $9 \%$ & $17 \%$ & $22 \%$ & $9 \%$ & $13 \%$ & $22 \%$ & $4 \%$ & $4 \%$ & $100 \%$ & $\mathrm{X}$ \\
\hline Velikost obvodů & SLO & HR & BiH & SRJ & SRB & MNE & RKS & MK & Celkem \\
\hline Počet obvodů & 1 & 2 & 2 & 2 & 2 & 4 & 0 & 1 & 14 & $20 \%$ \\
\hline Úroveň aplikace uzavírací klauzule & 1 & 2 & 2 & 2 & 2 & 3 & 0 & 1 & 13 & $19 \%$ \\
\hline Uzavírací klauzule a omezení & 2 & 1 & 1 & 0 & 1 & 2 & 1 & 0 & 8 & $11 \%$ \\
\hline postupu & 2 & 1 & 0 & 1 & 3 & 1 & 0 & 9 & $13 \%$ \\
\hline Další přerozdělení a jeho parametry & 5 & 0 & 2 & 0 & 0 & 0 & 0 & 0 & 7 & $10 \%$ \\
\hline Př́stup k menšinám & 0 & 2 & 0 & 0 & 1 & 2 & 1 & 0 & 6 & $9 \%$ \\
\hline Celková velikost shromáždění & 1 & 0 & 1 & 0 & 0 & 2 & 0 & 1 & 5 & $7 \%$ \\
\hline Volební formule & 2 & 1 & 1 & 0 & 0 & 0 & 0 & 0 & 4 & $6 \%$ \\
\hline Podoba hlasování & 1 & 1 & 1 & 0 & 0 & 0 & 1 & 0 & 4 & $6 \%$ \\
\hline Celkem & 15 & 10 & 11 & 4 & 7 & 16 & 4 & 3 & 70 & $100 \%$ \\
\hline & $21 \%$ & $14 \%$ & $16 \%$ & $6 \%$ & $10 \%$ & $23 \%$ & $6 \%$ & $4 \%$ & $100 \%$ & $X$ \\
\hline
\end{tabular}

Zdroj: Autor. 
Specifickou součástí naprosté většiny postjugoslávských volebních systémů je zvláštní př́stup k národnostním menšinám (viz Tabulka č. 6). Speciální obvody pro zástupce národnostních menšin byly vytvořeny ve Slovinsku již od roku 1990 (2,22,5 \% mandátů), Chorvatsku od 1992 (3,3-13\%), Kosovu od 2001 (16,7\%), Černé Hoře mezi lety 1998 a 2012 (5,3-6,5 \%). Nižší uzavírací klauzule pro strany menšin pak byla zavedena v Srbsku od roku 2007 (0 \%), Černé Hoře od $2012(0,35-0,7$ \%) a Kosovu od 2007 (0 \%). Žádný specifický př́stup k národnostním menšinám se nevyskytuje v Bosně a Hercegovině (zde jsou ale od roku 1996 jednotlivé entity reflektovány ve volebních obvodech), SRJ, Makedonii (zde má však od r. 2002 jeden z obvodů převážně albánské obyvatelstvo), do 1992 v Chorvatsku (většinový systém), do 2007 v Srbsku a do 1998 v Černé Hoře. Specifický prrístup pak byl také ve dvou př́padech zvolen pro voliče ze zahraničí - diasporu: Speciální obvod je takto zaveden od roku 1995 v Chorvatsku, v Makedonii pak od r. 2011. v obou pŕípadech bylo cílem posílit HDZ, respektive VMRO-DPMNE.

Volební design začal ve všech entitách kromě SRJ dříve nebo později specificky přistupovat $\mathrm{k}$ národnostním menšinám, at' už vytvořením speciálních národnostně definovaných obvodů, respektive vyčleněním národnostně definovaných mandátů, nebo snížením či zrušením uzavírací klauzule pro strany zastupující národnostní menšiny, či tím, že volební obvody reflektují geografické rozprostření národnostních menšin. Již od prvních voleb byl specifický př́stup využit ve Slovinsku a Kosovu. Naopak nejpozději k němu došlo v př́ípadě Srbska. v Bosně a Hercegovině a Makedonii (a dříve v SRJ) není specifický prístup $\mathrm{k}$ zastoupení menšin explicitně stanoven, ale volební obvody reflektují rozprostření hlavních národnostních skupin.

Tabulka č. 6

\begin{tabular}{|c|c|c|c|c|}
\hline \multicolumn{5}{|c|}{ Přístup k národnostním menšinám } \\
\hline & $\begin{array}{l}\text { Speciální } \\
\text { obvody }\end{array}$ & $\begin{array}{c}\text { Nižší uzavírací } \\
\text { klauzule }\end{array}$ & $\begin{array}{c}\text { Bez speciálního } \\
\text { přístupu }\end{array}$ & $\begin{array}{c}\text { (Speciální obvod } \\
\text { diaspory) }\end{array}$ \\
\hline SLO & 1990- & & & \\
\hline$H R$ & 1992- & & 1990-1992 & 1995- \\
\hline $\mathrm{BiH}$ & & & 1990-* & \\
\hline SRJ & & & 1990-2006 & \\
\hline SRB & & 2007- & 1990-2007 & \\
\hline MNE & 1998-2012 & 2012- & 1990-1998 & \\
\hline RKS & 2001- & 2007- & & \\
\hline MK & & & 1990-* & 2011- \\
\hline
\end{tabular}

Zdroj: Autor.

V postjugoslávské oblasti lze nalézt podobné trendy ve volebním designu a reformách mezi jednotlivými státními entitami, respektive jejich skupinami (viz 
Tabulka č. 7). Nejstabilnějš́ jsou volební systémy Slovinska a Kosova s rigidním designem, malou frekvencí reforem a pouze poměrnými systémy. Relativně stabilní je systém $\mathrm{v}$ Makedonii, kde ale $\mathrm{v}$ rámci flexibilního designu došlo na přelomu tisíciletí ke dvěma velkým reformám a jedné malé. Relativně nestabilní jsou systémy Chorvatska a Srbska, kde dochází k poměrně častým reformám v rámci flexibilního designu. v období nekonsolidované demokracie a polosoutěživosti v devadesátých letech se v nich uskutečnily mj. velké reformy. v novém tisíciletí se pak vyskytují pouze malé reformy $\mathrm{v}$ podobě reforem pro výsledek reformy a $\mathrm{v}$ potenciálně inkluzivním směru. Do této skupiny svými charakteristikami patríla také SRJ (ale s rigidním designem). Ve (zbytkové) skupině systémů Bosny a Hercegoviny (přes rigidní design) a Černé Hory sice nedošlo k velkým reformám, zato jsou zde poměrně časté malé reformy převáženě pro výsledek reformy. v postjugoslávském prostoru tedy lze vysledovat také určité společné trendy mezi jednotlivými systémy. Nicméně důvody, proč jednotlivé skupiny systémů v důsledku vykazují podobné charakteristiky, jsou rozdílné a až na výjimky $\mathrm{v}$ nich nelze hledat jasné př́íćny a důsledky. 
Tabulka č. 8

\begin{tabular}{|c|c|c|c|c|c|c|c|c|c|c|c|c|c|}
\hline \multicolumn{14}{|c|}{ Trendy volebního designu a reforem } \\
\hline $\begin{array}{l}\text { Státní } \\
\text { entita }\end{array}$ & Období & Demokratizace & $\begin{array}{l}\text { Politcký režim } \\
\text { (fakticky) }\end{array}$ & Stranický systém & $\begin{array}{l}\text { Právní } \\
\text { limity }\end{array}$ & $\begin{array}{l}\text { První } \\
\text { využití } \\
\text { PR list }\end{array}$ & \begin{tabular}{|c|} 
Jiným \\
systém než \\
PR list \\
(roky) \\
\end{tabular} & $\begin{array}{l}\text { Velké } \\
\text { reformy }\end{array}$ & $\begin{array}{l}\text { Malé } \\
\text { reformy }\end{array}$ & $\begin{array}{l}\text { Celkem } \\
\text { reforem }\end{array}$ & $\begin{array}{c}\text { Stejný } \\
\text { volební } \\
\text { design } \\
\text { (roky) } \\
\end{array}$ & $\begin{array}{l}\text { Převažující } \\
\text { typ malých } \\
\text { reforem pro }\end{array}$ & $\begin{array}{l}\text { Př́stup } \\
\text { k národno } \\
\text { stním } \\
\text { menšinám } \\
\end{array}$ \\
\hline SLO & $1990-$ & demokracie & parlamentní & $\begin{array}{l}\text { extrémní } \\
\text { multipartismus }\end{array}$ & rigidní & 1. & 0 & 0 & 2 & 2 & 8,3 & $\begin{array}{l}\text { výsledek } \\
\text { reformy } \\
\text { inkluzivní }\end{array}$ & obvody \\
\hline RKS & 2001- & $\begin{array}{l}\text { demokratizující } \\
\text { se }\end{array}$ & parlamentní & $\begin{array}{l}\text { extrémní } \\
\text { multipartismus }\end{array}$ & rigidní & 1. & 0 & 0 & 1 & 1 & 7,0 & $\begin{array}{l}\text { výsledek } \\
\text { reformy } \\
\text { exkluzivní }\end{array}$ & $\begin{array}{l}\text { obvody, } \\
\text { klauzule }\end{array}$ \\
\hline MK & $1990-$ & $\begin{array}{l}\text { demokratizující } \\
\text { se }\end{array}$ & parlamentní & $\begin{array}{l}\text { omezený } \\
\text { multipartismus }\end{array}$ & flexibilní & 4. & 13 & 2 & 1 & 3 & 6,3 & $\begin{array}{l}\text { reformu } \\
\text { inkluzivní }\end{array}$ & bez \\
\hline \multirow[b]{2}{*}{ SRB } & $\begin{array}{l}1990- \\
2000 \\
\end{array}$ & nedemokracie & $\begin{array}{l}\text { poloprezidents } \\
\text { ký }\end{array}$ & $\begin{array}{l}\text { polosoutěživý } \\
\text { s predominantními s. }\end{array}$ & flexibilní & 2. & 2 & 1 & 1 & 2 & \multirow[b]{2}{*}{5,2} & bez převahy & bez \\
\hline & $2000-$ & $\begin{array}{l}\text { demokratizující } \\
\text { se }\end{array}$ & $\begin{array}{l}\text { poloprezidents } \\
\text { ký }\end{array}$ & $\begin{array}{l}\text { atomizovaný } \\
\text { multipartismus }\end{array}$ & flexibilní & & & 0 & 2 & 2 & & $\begin{array}{l}\text { výsledek } \\
\text { reformy } \\
\text { inkluzivní }\end{array}$ & klauzule \\
\hline \multirow[b]{2}{*}{ HR } & \begin{tabular}{|l|}
$1990-$ \\
2000 \\
\end{tabular} & nedemokracie & $\begin{array}{l}\text { poloprezidents } \\
\text { ký }\end{array}$ & $\begin{array}{l}\text { polosoutěživý } \\
\text { s predominantní s. }\end{array}$ & flexibilní & 4. & 11 & 2 & 1 & 3 & \multirow[b]{2}{*}{3,7} & $\begin{array}{l}\text { reformu } \\
\text { inkluzivní }\end{array}$ & obvody \\
\hline & $2000-$ & demokracie & parlamentní & $\begin{array}{l}\text { extrémní } \\
\text { multipartismus }\end{array}$ & flexibilní & & & 0 & 3 & 3 & & $\begin{array}{l}\text { výsledek } \\
\text { reformy } \\
\text { inkluzivní }\end{array}$ & obvody \\
\hline SRJ & \begin{tabular}{|l|}
$1992-$ \\
2000 \\
\end{tabular} & nedemokracie & $\begin{array}{l}\text { poloprezidents } \\
\text { ký }\end{array}$ & $\begin{array}{l}\text { polosoutěživý } \\
\text { s predominantními s. }\end{array}$ & rigidní & 2. & 1 & 1 & 2 & 3 & 2,4 & reformu & $\begin{array}{l}\text { bez } \\
\text { (obvody) }\end{array}$ \\
\hline MNE & 1990- & $\begin{array}{l}\text { demokratizující } \\
\text { se }\end{array}$ & $\begin{array}{l}\text { parlamentní } \\
\text { se silným } \\
\text { prezidentem }\end{array}$ & $\begin{array}{l}\text { extrémní } \\
\text { multipartismus } \\
\text { s predominantní s. }\end{array}$ & flexibilní & 1. & 0 & 0 & 5 & 5 & 3,8 & $\begin{array}{l}\text { výsledek } \\
\text { reformy } \\
\text { inkluzivní }\end{array}$ & $\begin{array}{l}\text { obvody, } \\
\text { klauzule }\end{array}$ \\
\hline $\mathrm{BiH}$ & 1990- & nedemokracie & parlamentní & $\begin{array}{l}\text { atomizovaný } \\
\text { multipartismus }\end{array}$ & rigidní & 1. & 0 & 0 & 5 & 5 & 4,2 & $\begin{array}{l}\text { výsledek } \\
\text { reformy } \\
\text { exkluzivní }\end{array}$ & $\begin{array}{l}\text { bez } \\
\text { (obvody) }\end{array}$ \\
\hline
\end{tabular}

Zdroj: Autor. 


\section{Závěr}

Většina voleb (téměř $90 \%$ do hlavních komor parlamentů proběhla v postjugoslávském prostoru ve zkoumaném období na základě poměrných volebních systémů. Pouze ve 4 prrípadech z 60 bylo využito dvoukolového většinového systému a $\mathrm{v}$ dalších 4 prípadech smíšeného paralelního systému. Všechny entity, které $\mathrm{v}$ prvních volbách využily jiný než poměrný systém, přešly na poměrný nejpozději ve čtvrtých volbách. Zároveň žádná z entit, která pro první volby zavedla poměrný systém, jej nereformovala na jiný typ volebního systému. Obecně př́mé či postupné přechody k poměrnému systému souvisely s otevřením politické soutěže, demokratizací a se změnou poloprezidentských režimů na parlamentní. V postjugoslávské oblasti lze tak identifikovat jasný trend využívání poměrných volebních systémů, resp. přechodu $\mathrm{k}$ nim, což je $\mathrm{v}$ souladu s obecným trendem identifikovaným autory jako jsou např. Dieter Nohlen či Josep Colomer.

Celkem se ve sledovaném období uskutečnilo 29 reforem volebních systémů (průměr 3,6 na entitu). $Z$ toho se $v$ pětině prípadů jednalo o velké reformy, kdy došlo ke změně typu volebního systému, a ve čtyřech pětinách o malé reformy, kdy byly upraveny parametry $\mathrm{v}$ rámci stejného typu systému. $\mathrm{V}$ průměru se uskutečnila reforma volebního systému téměř před každými druhými volbami (1,8 roku), resp. v o něco delším intervalu, než činí jedno standardní čtyřleté volební období (4,7 roku). V postjugoslávské oblasti tedy obecně dochází $\mathrm{k}$ velmi častým reformám volebních systémů a volební design je značně nestabilní, což není vzhledem k turbulentnímu vývoji tamější politické situace $\mathrm{v}$ uplynulých 25 letech překvapivé.

Mezi jednotlivými entitami se samozřejmě vyskytly rozdíly v množství a typech reforem volebních systémů. Z celkových 6 velkých reforem se jedna uskutečnila v Srbsku a SRJ a dvě v Chorvatsku a Makedonii. Ve Slovinsku, Bosně a Hercegovině, Černé Hoře a Kosovu naproti tomu neproběhla žádná velká reforma. Přestože k velkým reformám došlo v období nekonsolidované demokracie, polosoutěživosti či silné role prezidentů, tak všechny velké reformy proběhly se zapojením opozice, směřovaly potenciálně inkluzivním směrem a byl $\mathrm{v}$ nich přijat poměrnější design. Velké reformy tedy nebyly povětšinou využívány prímo $\mathrm{k}$ intencionálnímu volebnímu inženýrství, ale spíše k nápravě faktorů politického systému vnímaných jako dysfunkční. Malé reformy se na rozdíl od velkých uskutečnily ve všech zkoumaných entitách. Povětšinou sloužily k nápravě dysfunkcí systému, ale zhruba ve třetině prrípadů byly využívány $\mathrm{k}$ intencionálnímu volebnímu inženýrství, a to především $\mathrm{v}$ devadesátých letech a $\mathrm{v}$ systémech s nekonsolidovanou demokracií. V novém tisíciletí pak již převládají reformy, které mají za cíl upravit parametry systémů považované více či méně za dysfunkční.

Dalším identifikovaným trendem je specifický přístup k národnostním menšinám, resp. jejich zvýhodnění, ve volebním designu. Ve všech entitách (kromě SRJ) byl postupně zaveden volební design, který reflektuje či usnadňuje zastoupení stran nebo zástupců (některých) národnostních menšin. Př́činou specifického 
prŕstupu je kromě samotné národnostní heterogenity obyvatelstva také zkušenost s občanskými konflikty a snaha přímo či nepřímo prrítomných mezinárodních aktérů (především v Bosně a Hercegovině a v Kosovu) o institucionální nastavení umožňující prímou reprezentaci národnostně definovaných skupin obyvatel. Přestože specifický př́stup $\mathrm{k}$ (některým) národnostním menšinám je zaveden v řadě (i evropských) volebních systémů, takto široké využití v celém regionu je poměrně ojedinělé. Inspirace pro institucionální nastavení včetně výběru volebního designu byla u části prípadů hledána u konceptu konsociačního uspořádání, který je využíván v naprosté většině případů akomodace rozdělených společností.

Systematický a detailní popis vývoje volebního designu a reforem v jednotlivých postujugoslávských politických systémech pomáhá doplnit informace a prrípadně upresnit nejasnosti týkající se dané problematiky. Přehled volebního designu a reforem v postjugoslávské oblasti může sloužit jednak jako datový a informační základ pro detailnější případové studie jednotlivých politických systémů, volebních reforem či situací, kdy k navrhovaným reformám nedošlo, popř. k detailnějšímu zkoumání volební integrity. Zároveň ale může být využit pro širší komparativní studie, kde $\mathrm{v}$ mnoha prúpadech dochází $\mathrm{k}$ opomenutí zařazení jednotlivých zkoumaných př́padů či celé oblasti, často právě z důvodu nedostupnosti spolehlivých dat.

Komparace a kontextualizace reforem volebního designu postjugoslávské oblasti je pak spíše př́spěvkem ke komparativním volebním studiím. Identifikace společných trendů ale i odlišností přispívá ke komplexnímu zkoumání tamějších politických systémů a obecně postjugoslávské politiky. Zároveň je možným základem pro další komparace volebního designu, reforem a inženýrství nejen $\mathrm{v}$ (jiho)východní Evropě, ale také obecně v demokratizujících se režimech, desintegrujících se státních entitách či v národnostně rozdělených společnostech, kde mezi sebou na teoretickém poli „,soupeří“ empiricky frekventované koncepty konsociačního uspořádání definované především Arendem Lijphartem a naopak v praxi jen ojediněle využívané koncepty centripetalismu reprezentované Donaldem Horowitzem nebo Benjaminem Reillym. V neposlední řadě je pak třeba zmínit limity využití př́stupo̊ zkoumání volebních reforem a inženýrství v podání př́stupu Alana Renwicka, které se ukazují při rozsáhlejších komparativních výzkumech jako př́liš detailní na kontextuální informace, a naopak vhodnost (doplněných) přístupů Richarda Katze a Matthewa Shugarta, které umožňují komparaci i za situace ne zcela podrobných informací o kontextu jednotlivých reforem. 


\section{Literatura a prameny ${ }^{57}$}

Balík, Stanislav (2002): „Republika Srbsko.“ In: Petr Fiala, Maxmilián Strmiska a Jan Holzer (eds.), Politické strany ve stredni a východni Evropè. Ideové-politický profil, pozice a role politických stran $v$ postkomunistických zemich. Brno: Mezinárodní politologický ústav Masarykovy univerzity v Brně, 400-419.

Belloni, Roberto (2004): „Peacebuilding and Consociational Electoral Engineering in Bosnia and Herzegovina." International Peacekeeping 11(2): 334-353. DOI: 10.1080/1353331042000237300

Berisha, Dardan (2016): „The Politics of Electoral Systems in the Former Yugoslav Republic of Macedonia." Indiana Journal of Constitutional Design 2(1): 1-20.

Bieber, Florian (2003): „Montenegrin politics since the disintegration of Yugoslavia.“ In: Florian Bieber (ed.), Montenegro in Transition: Problems of Identity and Statehood, Baden-Baden: Nomos, 11-42.

Bieber, Florian (2010): „The party system of Montenegro.“ In: Věra Stojarová, a Peter Emerson (eds.), Party Politics in the Western Balkans. New York: Routledge, 119-130.

Bielasiak, Jack a John Hulsey (2013): „Party system determinants of electoral reform in post-communist states." Communist and Post-Communist Studies 46: 1-12. DOI: 10.1016/j.postcomstud.2012.12.001

Birch, Sarah (2003): Electoral Systems and Political Transformation in Post-Communist Europe, New York: Palgrave Macmillan.

Blais, André a Louis Massicotte (2002): „Electoral Systems.“ In: Lawrence LeDuc, Richard G. Niemi a Pippa Norris (eds.), Comparing Democracies 2: New Challenges in the Study of Elections and Voting. Thousand Oaks: Sage, 40-69.

Bochsler, Daniel (2008): „The parliamentary election in Serbia, 21 January 2007.“ Electoral Studies 27(1): 160-165. DOI: 10.1016/j.electstud.2007.10.002

Bochsler, Daniel (2010): ,The party system of Serbia.“ In: Věra Stojarová a Peter Emerson (eds.), Party Politics in the Western Balkans. New York: Routledge, 131-150.

Bosnia and Herzegovina (2009): Constitution of Bosnia and Herzegovina, 1995.

Cabada, Ladislav (2003): „Koncepce stranických rodin a její problematická aplikace na středoevropské modely - př́klad stranického systému Republiky Slovinsko." Politologický časopis 10(3): 262-268.

Cabada, Ladislav (2004a): „Jugoslávie (Srbsko a Černá Hora).“ In: Michal Kubát (ed.), Politické a ústavni systémy zemi stredovýchodni Evropy. Praha: Eurolex Bohemia,159-177.

Cabada, Ladislav (2004b): „Makedonie.“ In: Michal Kubát (ed.), Politické a ústavní systémy zemi stredovíchodni Evropy. Praha: Eurolex Bohemia, 236-254.

Cabada, Ladislav (2005): Politický systém Slovinska. Praha: Sociologické nakladatelství.

Cabada, Ladislav (2008a): „Jugoslávie: Základní charakteristiky politického systému Titovy SFRJ.“ In: Ladislav Cabada (ed.), Komparace politických systémů: Nové demokracie strední a východni Evropy. Praha: Oeconomica, 220-236.

Cabada, Ladislav (2008b): „Slovinsko: Mezi tradicionalismem a postmodernou.“ In: Ladislav Cabada (ed.), Komparace politických systému: Nové demokracie stredni a východni Evropy. Praha: Oeconomica, 237-261.

57 Všechny elektronické zdroje jsou aktuální k 31. srpnu 2016. 
Cabada, Ladislav (2011): „Typology of Slovene minorities and differences in their status and rights." The Annual of Language \& Politics and Politics of Identity (5): 23-40.

Cabada, Ladislav (2015a): „Od delegace k soutěživým volbám: Cesta k personalizovanému proporčnímu volebnímu systému ve Slovinsku." In: Jakub Charvát (ed.), Pokušení vládnoucich: politika volebních reforem ve střední Evropě. Praha: Metropolitan University Prague Press, 80-94.

Cabada, Ladislav (2015b): „Lid vs. politické strany vs. Ústavní soud: spor o výklad referenda o volebním systému jako pokračování střetu levice a pravice ve Slovinsku.“ In: Jakub Charvát (ed.), Pokušeni vládnoucich: politika volebnich reforem ve strédní Evropè. Praha: Metropolitan University Prague Press, 80-94.

Centralna izborna komisija Bosne i Hercegovine (2016): Statistika iz̧bora [online]. Dostupné z: http://www.izbori.ba/Default.aspx?CategoryID=48\&Lang=3\&Mod=4.

Colomer, Josep Maria (2005): „It's Parties That Choose Electoral Systems (or, Duverger's Laws Upside Down)." Political Studies 53: 1-21. DOI: 10.1111/j.1467-9248.2005.00514.x

Colomer, Josep Maria, ed. (2004): Handbook of Electoral System Choice. New York: Palgrave Macmillan.

Dalton, Russell J. (2002): „Political Cleavages, Issues, and Electoral Change.“ In: Lawrence LeDuc, Richard G. Niemi a Pippa Norris (eds.), Comparing Democracies 2: New Challenges in the Study of Elections and Voting. Thousand Oaks: Sage, 189-209.

Državna izborna komisija Crne Gore (2016): Iqbori [online]. Dostupné z: http://rik.co.me/.

Državno izborno povjerenstvo Republike Hrvatske (2016): Arbiva iz̨bora [online]. Dostupné z: http://www.izbori.hr/izbori/dip_ws.nsf/public/index?openform.

Džankić, Jelena (2012): „Montenegro’s Minorities in the Tangles of Citizenship, Participation, and Access to Rights." Journal on Ethnopolitics and Minority Issues in Europe 11(3): 40-59.

Economist Intelligence Unit, The (2012). Democracy Index 2012, London, The Economist Intelligence Unit, $44 \mathrm{~s}$.

European Union (2016): EU Election observation missions [online]. Dostupné z: http:/ / eeas.europa.eu/eueom/index_en.htm.

Federal Republic of Yugoslavia (1992): Constitution of the Federal Republic of Yugoslavia.

Filip, Jan a Karel Schelle (1992): Vývoj a současnost voleb a volebního práva v ČSFR. Brno: Masarykova univerzita.

Fink-Hafner, Danica, Damjan Lajh a Alenka Krašovec (2011): „Electoral Engineering and its Impact in the Former Yugoslav Republics. " Politics in Central Europe 7(1): 7-34.

Freedom House (2016): Freedom in the World [online]. Dostupné z: http:/ /www.freedomhouse.org/report-types/freedom-world.

Gallagher, Michael a Paul Mitchell, eds. (2008): The Politics of Electoral Systems. New York: Oxford University Press.

Gallenkamp, Marian a Steffen Krassner (2010): „Slovenia.“ In: Dieter Nohlen a Philip Stöver (eds.), Elections in Europe: a Data Handbook. Baden-Baden: Nomos, 1761-1802.

Hague, Rod a Martin Harrop (2010): Comparative Government and Politics. New York: Palgrave Macmillan.

Hladký, Ladislav (2010): Slovinsko. Praha: Libri.

Hloušek, Vít (1999): „Uměle vytvořená většina? Politický systém Chorvatska.“ Politologický časopis 6(4): 414-433. 
Hloušek, Vít (2001): „Slovinský stranický systém a model umírněného pluralismu.“ Stredoevropské politické studie 3(1): nestránkováno

Hloušek, Vít (2004): „Chorvatsko.“ In: Michal Kubát (ed.), Politické a ústavní systémy zemí stredovýchodni Evropy. Praha: Eurolex Bohemia, 137-158.

Hloušek, Vít (2005): „Politické strany a stranické systémy ve srovnávací a teoretické perspektivě.“ In: Strmiska, Maxmilián (ed.), Politické strany moderni Evropy. Praha: Portál, 529-550.

Hloušek, Vít (2008): „Chorvatsko: Mezi pokušením autoritatismu a evropskou integrací.“

In: Ladislav Cabada (ed.), Komparace politických systémü: Nové demokracie stredni a východní Evropy. Praha: Oeconomica, 162-281.

Hloušek, Vít a Lubomír Kopeček (2005): „Politické strany a stranické systémy ve srovnávací a teoretické perspektivě.“ In: Strmiska, Maxmilián (ed.), Politické strany moderní Evropy. Praha: Portál, 9-54.

Horowitz, Donald L. (2003): „Electoral Systems: a Primer for Decison Makers.“ Journal of Democracy 14(4): 115-127. DOI: 10.1353/jod.2003.0078

Charvát, Jakub (2013): Politika volebnich reforem v ČR po roce 1989. Praha: Grada.

Charvát, Jakub (2015a): „Politika volebních reforem jako podobor současné volební analýzy." In: Jakub Charvát (ed.), Pokušení vládnoucích: politika volebních reforem ve strední Evropě. Praha: Metropolitan University Prague Press, 11-19.

Charvát, Jakub (2015b): „Politika volebních reforem: analytický rámec.“ In: Jakub Charvát (ed.), Pokušeni vládnoucich: politika volebnich reforem ve stredni Evropě. Praha: Metropolitan University Prague Press, 20-47.

Chytilek, Roman, Jakub Šedo, Tomáš Lebeda a Dalibor Čaloud (2009): Volební systémy. Praha: Portál.

Integrated Network for Societal Conflict Research (2016): Data Page [online]. Dostupné z: http://www.systemicpeace.org/.

Kasapović, Mirjana (2000): „Electoral Politics in Croatia 1990 - 2000.“ Politička misao 37(5): 3-20.

Kasapović, Mirjana (2010a): „Bosnia.“ In: Dieter Nohlen a Philip Stöver (eds.), Elections in Europe: a Data Handbook. Baden-Baden: Nomos, 319-350.

Kasapović, Mirjana (2010b): „Croatia.“ In: Dieter Nohlen a Philip Stöver (eds.), Elections in Europe: a Data Handbook. Baden-Baden: Nomos, 399-426.

Kasapović, Mirjana (2010c): „Macedonia.“ In: Dieter Nohlen a Philip Stöver (eds.), Elections in Europe: a Data Handbook. Baden-Baden: Nomos, 1271-1294.

Kasapović, Mirjana (2010d): „Serbia.“ In: Dieter Nohlen a Philip Stöver (eds.), Elections in Europe: a Data Handbook. Baden-Baden: Nomos, 1699-1732.

Kasapović, Mirjana (2012): „Voting Rights, Electoral Systems, and Political Representation of Diaspora in Croatia." East European Politics \& Societies 26(4): 777-791. DOI: $10.1177 / 0888325412450537$

Katz, Richard S. (2008): „Why are There so many (or so few) Electoral Reforms?“ In: Michael Gallagher a Paul Mitchell (eds.), The Politics of Electoral Systems. New York: Oxford University Press, 57-78.

Klíma, Michal (1998): Volby a politické strany v modernich demokraciich. Praha: Radix

Komar, Olivera a Zlatko Vujović (2007): „Europeanisation of National Political Parties and Party System: Case Study of Montenegro." Politics in Central Europe 3(1-2): 51-70. 
Krejčí, Oskar (2006): Nová kniha o volbách. Praha: Professional Publishing.

Krulík, Oldřich (2011): „Politická geografie: úvod do politické geografie.“ In: Miroslav Novák (ed.), Úvod do studia politiky. Praha: Sociologické nakladatelství, 203-253.

Kubát, Michal (2011): „Demokratické politické režimy.“ In: Miroslav Novák (ed.), Úvod do studia politiky. Praha: Sociologické nakladatelství, 697-723.

Lebeda, Tomáš (2008): Volebni systémy pomérnébo zastoupeni: mechanismy, proporcionalita a politické konsekvence, Praha: Karolinum.

LeDuc, Lawrence, Richard G. Niemi a Pippa Norris, eds. (2002): Comparing Democracies 2: New Challenges in the Study of Elections and Voting. Thousand Oaks: Sage.

Lijphart, Arendt (1994): Electoral Systems and Party Systems: a Study of Twenty-seven Democracies 1945-1990. Oxford: Oxford University Press.

Lipset, Seymour Martin a Stein Rokkan (1967): Party Systems and Voter Alignments: Crossnational Perspectives. New York: Free Press.

Manning, Carrie (2004): „Elections and Political Change in Post-War Bosnia and Herzegovina." Democratization 11(2): 60-86. DOI: 10.1080/13510340412331294212

Massicotte, Louis a André Blais (1999): „Mixed Electoral Systems: A Conceptual and Emipircal Survey." Electoral Studies 18(3): 341-366. DOI: 10.1016/S0261-3794(98)000638

Massicotte, Louis a André Blais (2000): „Constitutions and Elections“ In: Richard Rose (ed.), International Encyclopedia of Elections. London: Macmillan.

Mjekiqi, Shqipe a Michael Gallagher (2015): ,The parliamentary elections in Kosovo, June 2014.“ Electoral Studies 38: 106-109. DOI: 10.1016/j.electstud.2015.01.002

Montenegro (2007): Constitution of Montenegro.

Morrison, Kenneth (2009): Montenegro: a Modern History. London: I. B. Tauris.

Nohlen, Dieter (2010): „Elections and Electoral Systems.“ In: Dieter Nohlen a Philip Stöver (eds.), Elections in Europe: a Data Handbook. Baden-Baden: Nomos, 1-68.

Nohlen, Dieter a Philip Stöver, eds. (2010): Elections in Europe: a Data Handbook. BadenBaden: Nomos.

Norris, Pippa (2004): Electoral Engineering: Voting Rules and Political Behavior. New York: Cambridge University Press.

Novák, Miroslav (2011): „Strany a stranické systémy.“ In: Miroslav Novák (ed.), Úvod do studia politiky. Praha: Sociologické nakladatelství, 548-99.

Novák, Miroslav, ed.(2011): Úvod do studia politiky. Praha: Sociologické nakladatelství.

Nový, Michal a Vlastimil Havlík (2012): „Vládnutí v Chorvatsku: Tuđmanova smrt jako impuls pro koaliční spolupráci?"“ Acta Politologica 4(1): 71-97.

Organization for security and Co-operation in Europe (2016a): OSCE Mission in Kosovo Elections [online]. 2016. Dostupné z: http://www.osce.org/kosovo/105096.

Organization for Security and Co-operation in Europe (2016b): Republic of Croatia parliamentary elections 8 November 2015 OSCE/ODIHR Election Assessment Mission Final Report [online]. Dostupné z: http://www.osce.org/odihr/elections/croatia/ 223631?download $=$ true.

Pavićević, Veselin, ed. (2007): Izbori i izborno zakonodavstvo u Crnoj Gori: 1990-2006. Podgorica: CEMI - Centar za monitoring.

Pelikán, Jan (2009a): „Chorvatsko.“ In: Miroslav Šesták (ed.), Dẹjiny jïhoslovanských zemí. Praha: Lidové noviny, 609-626. 
Pelikán, Jan (2009b): „Socialistická Jugoslávie.“ In: Miroslav Šesták (ed.), Dẹjiny jihoslovanských zemí. Praha: Lidové noviny, 493-582.

Pelikán, Jan (2016): „Aktuální situace a perspektivy vývoje států západního Balkánu.“ In: Jan Pelikán (ed.), Státy západního Balkánu v uplynulém čtvrtstoletí a perspektivy jejich vývoje. Praha: Filozofická fakulta Univerzity Karlovy, 9-26.

Pirjevec, Jože (2000): Jugoslávie 1918-1992. Praha: Argo.

Podolnjak, Robert (2015): „Abolishing All Mechanisms for Fixing Elections: The Citizens' Initiative to Change the Electoral System of Croatia." Politicka misao 52(4-5): 101-123.

Polity IV Project (2016): Polity IV Project [online]. Dostupné z: http://www.systemicpeace.org/polity/polity4.htm.

Prtina, Srdjan (2005): „,,Východni“" vs. „západní" koncept nacionalismu: Př́pad Bosny a Hercegoviny." Politologický časopis 12(1): 27-39.

Renwick, Alan (2010): The Politics of Electoral Reform: Changing the Rules of Democracy. Cambridge: Cambridge University Press.

Renwick, Alan (2011): „Electoral Reform in Europe since 1945.“ West European Politics 34(3): 456-477. DOI: 10.1080/01402382.2011.555975

Republic of Kosovo (2008): Constitution of the Republic of Kosovo.

Republic of Macedonia (1991): Constitution of the Republic of Macedonia (2001, 2011).

Republic of Montenegro (1992): Constitution of the Republic of Montenegro.

Republic of Serbia (1990): Constitution of the Republic of Serbia.

Republic of Serbia (2006): Constitution of the Republic of Serbia.

Republika e Kosovës - Komisioni qendror i zgjedhjeve (2016): Skupštinski iz̧bori Rezultati [online]. Dostupné z: http://www.kqz-ks.org/en/parliamentary.

Republika Hrvatska (2011): Ustav Republike Hrvatske (1997, 1998, 2000, 2001, 2010, 2011).

Republika Makedonija - Državna izborna komisija (2016): Arhiva [online]. Dostupné z: http://www.sec.mk/.

Republika Slovenija - Državna volilna komisija (2016): Odločanje državljank in državlajnov [online]. Dostupné z: http://volitve.gov.si/.

Republika Slovenija (2016): Ustava Republike Slovenije (1997, 2000, 2003, 2004, 2006).

Republika Slovenije (1990): Poročilo o izidu glasovanja za izvolitev delegatov v družbenopolitični zbor Skupštine Republike Slovenije 8. in 22. aprila 1990. In: Uradni list Republike Slovenije Leto XLVII, Stevilka 17. ISSN 0350-4964.

Republika Srbija - Republička izborna komisija (2016): Rezultati iz̧bora [online]. Dostupné z: http://www.rik.parlament.gov.rs/latinica/arhiva.php.

Reynolds, Andrew (2000): „Designing Electoral Systems“ In: Richard Rose (ed.), International Encyclopedia of Elections. London: Macmillan, 58-66.

Reynolds, Andrew a Ben Reilly (eds.) (1997): The International IDEA Handbook of Electoral System Design. Stockholm: International Institute for Democracy and Electoral Assistance.

Reynolds, Andrew, Ben Reilly a Andrew Ellis (eds.) (2005): Electoral System Design: The New International IDE A Handbook. Stockholm: International Institute for Democracy and Electoral Assistance.

Romancov, Michael (2004): „Politická geografie a geopolitika.“ In: Ladislav Cabada a Michal Kubát (eds.), Úvod do studia politické védy. Praha: Eurolex Bohemia, 404-357.

Rose, Richard, ed. (2000): International Encyclopedia of Elections. London: Macmillan.

Rosůlek, Přemysl (2008a): Makedonie, Praha: Libri. 
Rosůlek, Přemysl (2008b): „Makedonie: Po demontáži národního státu Makedonců.“ In: Ladislav Cabada (ed.), Komparace politických systémü: Nové demokracie strédni a východní Evropy. Praha: Oeconomica, 162-281.

Rychlík, Jan (2011): „Samostatné Slovinsko.“ In: Jan Rychlík (ed.), Dějiny Slovinska. Praha: Lidové noviny, 238-267.

Rychlík, Jan (2016a): „Chorvatsko.“ In: Jan Pelikán (ed.), Státy západního Balkánu v uplynulém cturtstoletí a perspektivy jejich vývoje. Praha: Filozofická fakulta Univerzity Karlovy, 231-280.

Rychlík, Jan (2016b): „Makedonie.“ In: Jan Pelikán (ed.), Státy západního Balkánu v uplynulém ćtvrtstoleti a perspektivy jejich vývoje. Praha: Filozofická fakulta Univerzity Karlovy, 336-372.

Rychlík, Jan a Milan Perenćević (2007): Déjiny Chorvatska. Praha: Lidové noviny.

Rychlík, Jan a Miroslav Kouba (2003): Dějiny Makedonie. Praha: Lidové noviny.

Sartori, Giovanni (2001): Srovnávací uistavní inženýrství. Praha: Sociologické nakladatelství.

Sartori, Giovanni (2005): Strany a stranické systémy. Brno: Centrum pro studium demokracie a kultury.

Sekelj, Laslo (2000): „Parties and Elections: The Federal Republic of Yugoslavia - Change Without Transformation." Europe-Asia Studies 52(1): 57-75. DOI: $10.1080 / 09668130098262$

Shugart, Matthew S. (2008): „Inherent and Contingent Factors in Reform Initiation in Plurality Systems.“ In: André Blais (ed.), To Keep or To Change First Past The Post? Oxford: Oxford University Press, 7-60.

Skupština Crne Gore (2013): Complete results of parliamentary elections 1990-2012.docx., emailová korespondence s Jovanou Adžić <jovana.adzic@skupstina.me>

Socialist Federal Republic of Yugoslavia (1976): The Constitution of the Socialist Federal Republic of Yugoslavia <1974>, Merrick, Cross-Cultural Communications, ISBN 0-89304-006-1.

Songstad, Nils Gunnar (2004): Republic of Croatia: Parliamentary Elections 2003. The Norwegian Centre of Human Rights/NORDEM.

State Union of Serbia and Montenegro (2003): Constitutional Charter of the State Union of Serbia and Montenegro.

Stojarová, Věra (2010): „The party system of Kosovo.“ In: Věra Stojarová a Peter Emerson (eds.), Party Politics in the Western Balkans. New York: Routledge, 151-166.

Stojarová, Věra a Peter Emerson, eds. (2010): Party Politics in the Western Balkans. New York: Routledge.

Stöver, Philip a Marian Gallenkamp (2010): „Montenegro.“ In: Dieter Nohlen a Philip Stöver (eds.), Elections in Europe: a Data Handbook. Baden-Baden: Nomos, 1365-1378.

Strmiska, Maxmilián (1999): „The Macedonian Multipartism.“ Stredoevropské politické studie 1(1): nestránkováno.

Strmiska, Maxmilián (2000): „The Making of Party Pluralism in Montenegro." Stredoevropské politické studie 2(3): nestránkováno.

Strmiska, Maxmilián (2001): „Polarizací k dynamickému pluralismu? Případ černohorského multipartismu." Středoevropské politické studie 3(3): nestránkováno.

Szajkowski, Bogdan (1999): „Elections and Electoral Politics in Macedonia.“ Transitions 40 $(1-2): 55-82$.

Šedo, Jakub (2007): Volebni systémy postkomunistických zemí. Brno: Centrum pro studium demokracie a kultury.

Šedo, Jakub (2010a): „The party system of Bosnia and Herzegovina.“ In: Věra Stojarová a Peter Emerson (eds.), Party Politics in the Western Balkans. New York: Routledge, 85-98. 
Šedo, Jakub (2010b): „The party system of Croatia.“ In: Věra Stojarová a Peter Emerson (eds.), Party Politics in the Western Balkans. New York: Routledge, 73-84.

Šedo, Jakub (2010c): „The party system of Macedonia.“ In: Věra Stojarová a Peter Emerson (eds.), Party Politics in the Western Balkans. New York: Routledge, 167-179.

Š́stek, František (2008): Cerná Hora. Praha: Libri.

Taagepera, Rein (1998): „Effective Magnitude and Effective Threshold.“ Eletoral Studies 17(4): 393-404.

Taagepera, Rein a Matthew S. Shugart (1989): Seats and Votes: The Effects and Determinants of Electoral Systems. New Haven: Yale University Press.

Taylor, Andrew (2005): „Electoral systems and the promotion of 'consociationalism' in a multi-ethnic society. The Kosovo Assembly elections of November 2001." Electoral Studies 24(3): 435-463. DOI: 10.1016/j.electstud.2004.09.001

Tejchman, Miroslav a Jan Pelikán (2013): „Třetí Jugoslávie.“ In: Pelikán, Jan et. al., Dějiny Srbska. Praha: Lidové noviny, 507-550.

Vojtěchovský, Ondřej (2016): „Černá Hora.“ In: Jan Pelikán (ed.), Státy západního Balkánu v uplynulém čtvrtstoletí a perspektivy jejich vývoje. Praha: Filozofická fakulta Univerzity Karlovy, 73-135.

Vujica, Dragoljub (ed.) (1980): Constitutional System of Yugoslavia. Belgrade: Jugoslovenska stvarnost.

Vuković, Ivan (2010): „The post-communist political transitiv of Montenegro: Democratization prior to Europeanization." Contemporary European Studies 5(2): 59-76.

Ž́la, Ondřej (2016): „Bosna a Hercegovina.“ In: Jan Pelikán (ed.), Státy západního Balkánu $v$ uplynulém ćturtstoletí a perspektivy jejich vývoje. Praha: Filozofická fakulta Univerzity Karlovy, 73-135.

\section{Electoral Design, Reforms, and Engineering in the Post- Yugoslav State Entities, 1990-2015}

\section{SUMMARY}

Voters in Yugoslavia did not cast their ballots for the parliament directly until 1990. The first direct elections in 1990 were not held to the federal parliament, but only to the assemblies of the federal republics (prior to which all political posts had been appointed by the method of delegation). In the first direct elections, proportional representation electoral systems (List PR) were employed in half of the elections (Slovenia, BiH, and Montenegro) to the main chamber and two round majority systems (TRS) in the other half of elections (Croatia, Serbia, and Macedonia). a mixed parallel system was introduced for the first elections in the Federal Republic of Yugoslavia (FRY) in 1992 and List PR was implemented for the first elections in Kosovo in 2001. List PR has been used in almost $90 \%$ of all elections (52 out of 60) in the post-Yugoslav systems during the researched period between 1990 and 2015. TRS and mixed parallel systems were both used only in four elections (both 7\%). List PR was introduced in the fourth elections at the latest within the systems that had employed a non-proportional system for the first elections and there 
has been no change in the type of electoral system in entities that had introduced List PR for the first elections. a common trend of employing or adopting of List PR within the post-Yugoslav systems can be identified which also corresponds to a general trend of gradual increase of List PR use in Europe and worldwide.

Variables of electoral systems (including the type of system) are not part of the postYugoslav constitutions (apart from assembly size). The only exceptions can be found in the Slovenian (since 2000) and Kosovar (since 2008) constitutions, where rigid electoral design effectively prevents intentional electoral engineering. In addition to these two cases, $\mathrm{BiH}$ can also be classified as having a rigid electoral design in which the possibilities of electoral reform are limited by the presence of the external actors who (in)directly implemented the design (as in Kosovo). On the contrary, electoral design in Croatia, Serbia, Montenegro, and Macedonia can be referred as flexible, where a majority of all deputies is sufficient to carry out a reform.

Electoral system reforms are quite frequent in the post-Yugoslav region and electoral design is generally unstable there. In total, 29 electoral system reforms (an average of 3.6 reforms per entity) took place between 1990 and 2015. One-fifth of the cases (6) were major reforms (alternation of the type of electoral system) and four-fifths (23) were minor reforms (modification of variables within the same type of electoral system). An electoral system reform took place before almost every second election (1.8) in general or, other words, a little longer than one standard four-year term (4.7 years).

Significant differences can be found among particular systems in quantity and types of electoral reforms. There have been no major reforms in Slovenia, BiH, Montenegro, or Kosovo. One major reform occurred in Serbia and one in the FRY, and two major reforms took place in Croatia and Macedonia. Minor reforms, on the other hand, were present in all the researched systems (the most in Montenegro and $\mathrm{BiH}$ and the least in Kosovo and Macedonia).

Major reforms (Croatia 1992, 2000; FRY 1992/1993; Serbia 1992; Macedonia 1998, 2002) were carried out in systems with flexible electoral design, in which a simple majority of all deputies was sufficient to put through a reform of the type of electoral system (with the exception of the rigid electoral design in the FRY, where the government nevertheless had sufficient share of deputies because of the oppositional boycott of previous elections). The main purpose varied within the major reforms. There were reforms, settled with the opposition, which aimed to enhance the legitimacy and representativeness of the political system (Serbia 1992; FRY 1992/1993; Macedonia 1998) or which aimed to settle the conflict after the end of the insurgency (Macedonia 2002). However, there were also two reforms aimed at maintaining the positions of the government and weakening the opposition (Croatia 1992, 2000). Opposition was generally involved in the reforms (at least to certain degree) which retained a potentially inclusive direction; also, more proportional design was implemented, even though the major reforms took place in countries with unconsolidated democracy, semi-competitive party systems (with the exception of Macedonia in 1998 after the preceding elections had been boycotted, and in 2002 after the settlement of the armed conflict), and a strong role of the presidents (above all Tudman and Milošević). Straightforward or gradual transitions to List PR were related to the opening of political competition, democratization, and the change from semi-presidential to parliamentary regimes. Major reforms were not generally used for intentional electoral 
engineering, but rather within a wider context to correct those factors of the political system which were perceived as dysfunctional.

In contrast, minor reforms took place in all of the systems (most often in $\mathrm{BiH}$ and Montenegro, least often in Kosovo and Slovenia). The most frequently changed elements (variables) were the number of seats in constituencies and the number of constituencies. The least frequently reformed variables were the ballot structure and electoral formulas. More than two-thirds of the minor reforms were used as a tool to remedy system functions which were perceived as dysfunctional, while less than a third of minor reforms were introduced to increase the benefits of governing politicians (particularly in the 1990s, and within systems with unconsolidated democracy). Less than two-thirds of minor reforms were potentially inclusive and more than a third were potentially exclusive. Minor reforms were used mainly to correct dysfunctions of the systems (clearly prevalent in the new millennium). However, intentional electoral engineering was carried out via minor rather than major reforms.

A specific approach to representing national minorities can also be found in the postYugoslav electoral designs. Electoral design that reflects or facilitates representation of parties or the representatives of national minorities in the main chamber has been introduced in all the systems (except the FRY). Specifically, there are nationally defined constituencies, reserved seats, lower or cancelled legal thresholds or constituencies corresponding to the territorial concentration of national minorities. 


\section{Př́lohy}

Tabulka č. 8: Přehled volebního designu v postjugoslávském prostoru ${ }^{58}$

\begin{tabular}{|c|c|c|c|c|c|c|c|c|c|c|c|c|c|c|c|c|c|}
\hline 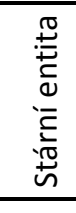 & $\begin{array}{l}\frac{0}{0} \\
\frac{0}{0} \\
\frac{3}{0} \\
\frac{\pi}{0} \\
\frac{20}{2} \\
\end{array}$ & $\begin{array}{l}\frac{0}{0} \\
\frac{0}{0} \\
\frac{0}{0} \\
\frac{1}{4}\end{array}$ & 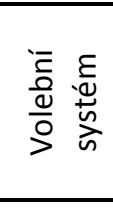 & $\begin{array}{l}\vec{\lambda} \\
\frac{\pi}{0} \\
\frac{\Gamma}{\pi} \\
\sum\end{array}$ & 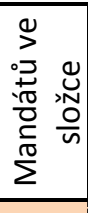 & 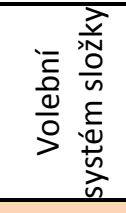 & 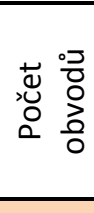 & 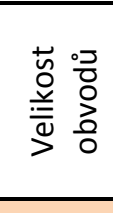 & 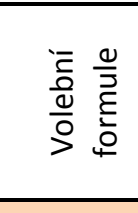 & 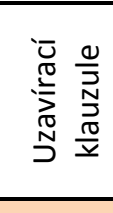 & 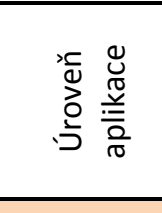 & 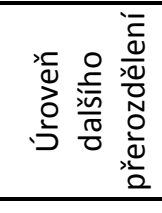 & 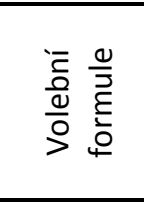 & 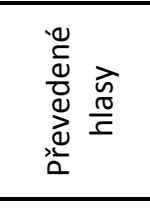 & 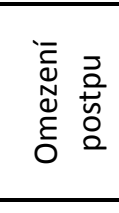 & 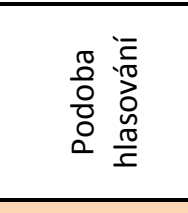 & $\begin{array}{l}\frac{\pi}{\tilde{D}} \\
\frac{\pi}{n} \\
\stackrel{N}{N} \\
0 \\
0\end{array}$ \\
\hline \multirow{15}{*}{ SLO } & \multirow[b]{2}{*}{1.} & \multirow[b]{2}{*}{1990} & \multirow{15}{*}{ PR list } & \multirow[b]{2}{*}{80} & 78 & PR List & 14 & 3 až 7 & D'Hondt & $2,50 \%$ & obvod & & $x$ & & & panašování & \\
\hline & & & & & 2 & $\begin{array}{l}\text { Borda } \\
\text { Count }\end{array}$ & 2 & 1 & \multicolumn{8}{|c|}{$x$} & $\begin{array}{l}1 \text { Italové; } 1 \\
\text { Mad'aři } \\
\end{array}$ \\
\hline & \multirow{2}{*}{2.} & \multirow{2}{*}{1992} & & \multirow{2}{*}{90} & 88 & PR List & 8 & 11 & Hare & $x$ & $\mathrm{x}$ & celostátní & D'Hondt & zbytkové & $\begin{array}{l}\min .3 \\
\operatorname{man} .\end{array}$ & $\begin{array}{l}\text { přísně } \\
\text { vázané }\end{array}$ & korigující funkce \\
\hline & & & & & 2 & $\begin{array}{l}\text { Borda } \\
\text { Count }\end{array}$ & 2 & 1 & \multicolumn{8}{|c|}{$x$} & $\begin{array}{l}1 \text { Italové; } 1 \\
\text { Mad'aři } \\
\end{array}$ \\
\hline & \multirow{2}{*}{3.} & \multirow{2}{*}{1996} & & \multirow{2}{*}{90} & 88 & PR List & 8 & 11 & Hare & $x$ & $x$ & celostátní & D'Hondt & zbytkové & $\begin{array}{l}\min .3 \\
\operatorname{man} .\end{array}$ & $\begin{array}{l}\text { přísně } \\
\text { vázané }\end{array}$ & korigující funkce \\
\hline & & & & & 2 & $\begin{array}{l}\text { Borda } \\
\text { Count }\end{array}$ & 2 & 1 & \multicolumn{8}{|c|}{$x$} & $\begin{array}{l}1 \text { Italové; } 1 \\
\text { Mad'aři } \\
\end{array}$ \\
\hline & \multirow{2}{*}{4.} & \multirow{2}{*}{2000} & & \multirow{2}{*}{90} & 88 & PR List & 8 & 11 & $\begin{array}{c}\mathrm{H}- \\
\text { Bischoff }\end{array}$ & $4 \%$ & celostátní & celostátní & D'Hondt & všechny & $\begin{array}{l}\text { kan. ve } \\
2 \text { obv. }\end{array}$ & $\begin{array}{l}\text { přísně } \\
\text { vázané }\end{array}$ & $\begin{array}{l}\text { kompenzační } \\
\text { funkce }\end{array}$ \\
\hline & & & & & 2 & $\begin{array}{l}\text { Borda } \\
\text { Count }\end{array}$ & 2 & 1 & \multicolumn{8}{|c|}{$x$} & $\begin{array}{l}1 \text { Italové; } 1 \\
\text { Mad'aři }\end{array}$ \\
\hline & \multirow{2}{*}{5.} & \multirow{2}{*}{2004} & & \multirow{2}{*}{90} & 88 & PR List & 8 & 11 & $\begin{array}{c}\mathrm{H}- \\
\text { Bischoff }\end{array}$ & $4 \%$ & celostátní & celostátní & D'Hondt & všechny & $\begin{array}{l}\text { kan. ve } \\
2 \text { obv. }\end{array}$ & $\begin{array}{l}\text { přísně } \\
\text { vázané }\end{array}$ & $\begin{array}{l}\text { kompenzační } \\
\text { funkce }\end{array}$ \\
\hline & & & & & 2 & $\begin{array}{l}\text { Borda } \\
\text { Count }\end{array}$ & 2 & 1 & \multicolumn{8}{|c|}{$x$} & $\begin{array}{l}1 \text { Italové; } 1 \\
\text { Mad'aři } \\
\end{array}$ \\
\hline & \multirow{2}{*}{6.} & \multirow{2}{*}{2008} & & \multirow{2}{*}{90} & 88 & PR List & 8 & 11 & $\begin{array}{c}\mathrm{H}- \\
\text { Bischoff }\end{array}$ & $4 \%$ & celostátní & celostátní & D'Hondt & všechny & $\begin{array}{l}\text { kan. ve } \\
2 \text { obv. }\end{array}$ & $\begin{array}{l}\text { přísně } \\
\text { vázané }\end{array}$ & $\begin{array}{l}\text { kompenzační } \\
\text { funkce }\end{array}$ \\
\hline & & & & & 2 & $\begin{array}{l}\text { Borda } \\
\text { Count } \\
\end{array}$ & 2 & 1 & \multicolumn{8}{|c|}{$\mathrm{X}$} & $\begin{array}{l}1 \text { Italové; } 1 \\
\text { Mad'aři }\end{array}$ \\
\hline & \multirow{2}{*}{7.} & \multirow{2}{*}{2011} & & \multirow{2}{*}{90} & 88 & PR List & 8 & 11 & $\begin{array}{c}\mathrm{H}- \\
\text { Bischoff }\end{array}$ & $4 \%$ & celostátní & celostátní & D'Hondt & všechny & $\begin{array}{l}\text { kan. ve } \\
2 \text { obv. }\end{array}$ & $\begin{array}{l}\text { přísně } \\
\text { vázané }\end{array}$ & $\begin{array}{l}\text { kompenzační } \\
\text { funkce }\end{array}$ \\
\hline & & & & & 2 & $\begin{array}{l}\text { Borda } \\
\text { Count }\end{array}$ & 2 & 1 & \multicolumn{8}{|c|}{$x$} & $\begin{array}{l}1 \text { Italové; } 1 \\
\text { Mad'aři }\end{array}$ \\
\hline & 8. & 2014 & & 90 & 88 & PR List & 8 & 11 & $\mathrm{H}-$ & $4 \%$ & celostátní & celostátní & D'Hondt & všechny & kan. ve & přísně & kompenzační \\
\hline
\end{tabular}

${ }^{58}$ Zdroje všech př́loh jsou patrné bud' přímo ze samotných př́loh, nebo z textu. Veškeré výpočty jsou provedené autorem. 


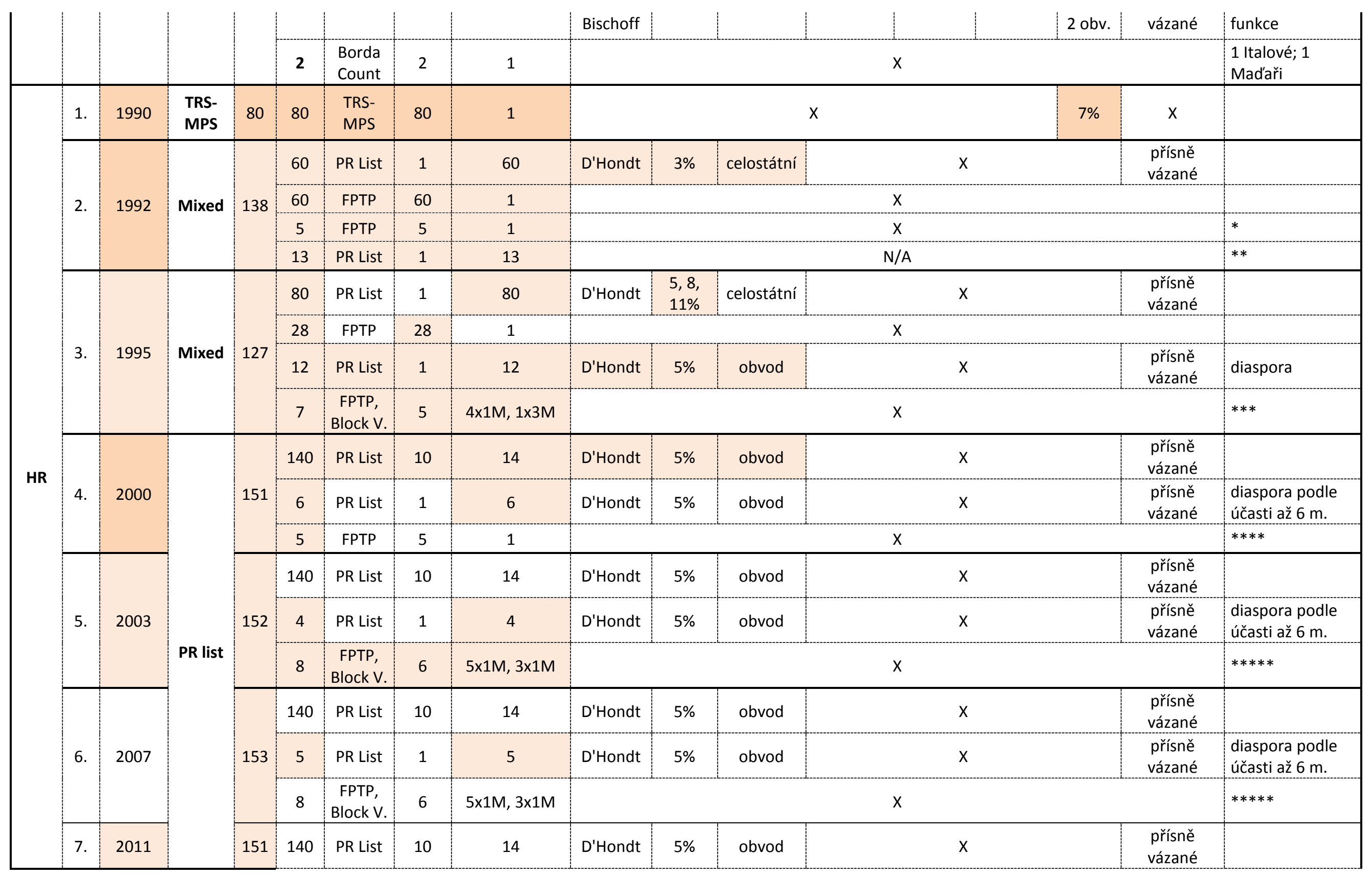




\begin{tabular}{|c|c|c|c|c|c|c|c|c|c|c|c|c|}
\hline & & & 3 & PR List & 1 & 3 & D'Hondt & $5 \%$ & obvod & $x$ & $\begin{array}{l}\text { př́sně } \\
\text { vázané }\end{array}$ & $\begin{array}{l}\text { diaspora } 3 \\
\text { mandáty }\end{array}$ \\
\hline & & & 8 & $\begin{array}{c}\text { FPTP, } \\
\text { Block V. }\end{array}$ & 6 & $5 \times 1 M, 3 \times 1 M$ & \multicolumn{5}{|c|}{$x$} & $* * * * *$ \\
\hline \multirow{3}{*}{8.} & \multirow{3}{*}{2015} & \multirow{3}{*}{151} & 140 & PR List & 10 & 14 & D'Hondt & $5 \%$ & obvod & $x$ & flexibilní & \\
\hline & & & 3 & PR List & 1 & 3 & D'Hondt & $5 \%$ & obvod & $x$ & flexibilní & $\begin{array}{l}\text { diaspora } 3 \\
\text { mandáty }\end{array}$ \\
\hline & & & 8 & $\begin{array}{c}\text { FPTP, } \\
\text { Block V. }\end{array}$ & 6 & $5 \times 1 M, 3 \times 1 M$ & \multicolumn{5}{|c|}{$x$} & $* * * * *$ \\
\hline
\end{tabular}

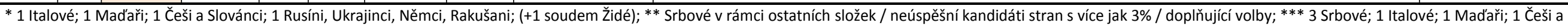

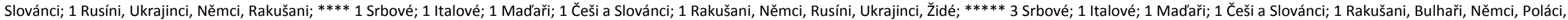

Romové, Rumuni, Rusíni, Rusové, Turci, Ukrajinci, Vlaši, Židé; 1 Albánci, Bosňáci, Černohorci, Makednonci, Slovinci

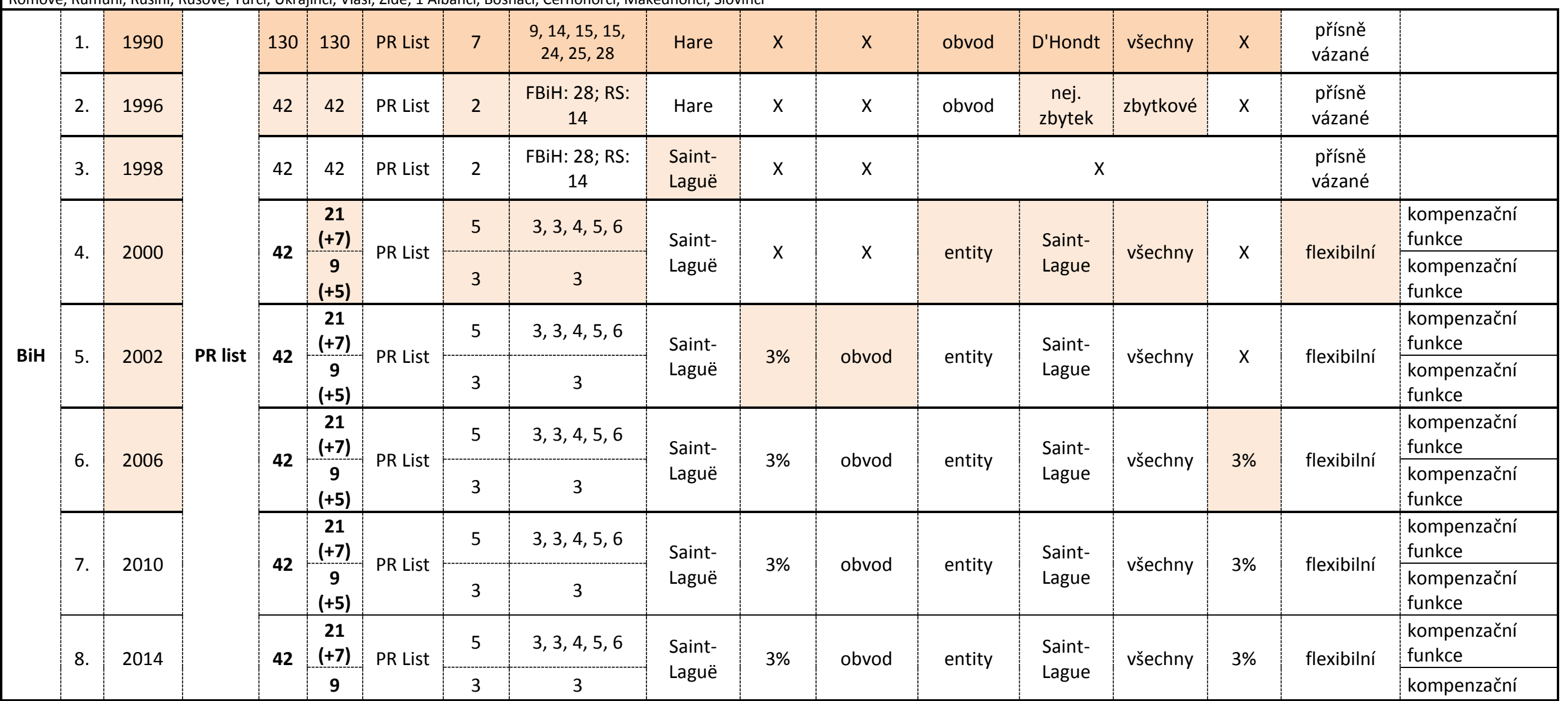




\begin{tabular}{|c|c|c|c|c|c|c|c|c|c|c|c|c|c|c|c|c|c|}
\hline & & & & & $(+5)$ & & & & & & & & & & & & funkce \\
\hline \multirow{5}{*}{ SRJ } & & & & & 58 & FPTP & $52+6$ & 1 & & & & & & & & & \\
\hline & 1. & 1992 & Mixed & 136 & 78 & PR List & 2 & $\begin{array}{c}\text { SRB: } 54 ; \text { MNE: } \\
24 \\
\end{array}$ & Hare & $5 \%$ & obvod & N/A & N/A & $\mathrm{N} / \mathrm{A}$ & N/A & $\begin{array}{l}\text { prísně } \\
\text { vázané }\end{array}$ & \\
\hline & 2. & $1992 / 3$ & \multirow{3}{*}{ PR list } & 138 & 138 & PR List & $\begin{array}{l}\text { S: } 9 \\
M: 1\end{array}$ & $\begin{array}{l}\text { SRB: N/A; } \\
\text { MNE: } 30\end{array}$ & D'Hondt & $5 \%$ & obvod & \multicolumn{4}{|c|}{$x$} & $\begin{array}{l}\text { přísně } \\
\text { vázané }\end{array}$ & \\
\hline & 3. & 1996 & & 138 & 138 & PR List & $\begin{array}{l}\text { S: } 29 \\
M: 7\end{array}$ & $\begin{array}{c}\text { SRB: } 3 \text { až 5; } \\
\text { MNE: }\end{array}$ & D'Hondt & $5 \%$ & obvod & \multicolumn{4}{|c|}{$x$} & $\begin{array}{l}\text { přísně } \\
\text { vázané }\end{array}$ & \\
\hline & 4. & 2000 & & 138 & 138 & PR List & $\begin{array}{l}S: 26, \\
M: 1\end{array}$ & $\begin{array}{c}\text { SRB: } 12 \times 3 \mathrm{M}, \\
7 \times 4 \mathrm{M}, 5 \times 5 \mathrm{M}, \\
1 \times 9 \mathrm{M}, 1 \times 10 \mathrm{M} ; \\
\text { MNE: } 30\end{array}$ & D'Hondt & $5 \%$ & obvod & \multicolumn{5}{|r|}{$\begin{array}{l}\text { př́sně } \\
\text { vázané }\end{array}$} & \\
\hline \multirow{10}{*}{ SRB } & 1. & 1990 & $\begin{array}{l}\text { TRS- } \\
\text { MS }\end{array}$ & 250 & 250 & TRS-MS & 250 & 1 & \multicolumn{8}{|c|}{$x$} & \\
\hline & 2. & 1992 & \multirow{9}{*}{ PR list } & 250 & 250 & PR List & 9 & 22 až 46 & D'Hondt & $5 \%$ & obvod & \multicolumn{4}{|c|}{$x$} & $N / A$ & \\
\hline & 3. & 1993 & & 250 & 250 & PR List & 9 & 22 až 46 & D'Hondt & $5 \%$ & obvod & \multicolumn{4}{|c|}{$x$} & N/A & \\
\hline & 4. & 1997 & & 250 & 250 & PR List & 29 & 6 až 14 & D'Hondt & $5 \%$ & obvod & \multicolumn{4}{|c|}{$x$} & N/A & \\
\hline & 5. & 2000 & & 250 & 250 & PR List & 1 & 250 & D'Hondt & $5 \%$ & celostátní & \multicolumn{4}{|c|}{$x$} & N/A & \\
\hline & 6. & 2003 & & 250 & 250 & PR List & 1 & 250 & D'Hondt & $5 \%$ & celostátní & \multicolumn{4}{|c|}{$x$} & N/A & \\
\hline & 7. & 2007 & & 250 & 250 & PR List & 1 & 250 & D'Hondt & $5 \%, 0 \%$ & celostátní & \multicolumn{4}{|c|}{$x$} & $\begin{array}{l}\text { přísně } \\
\text { vázané }\end{array}$ & $\begin{array}{l}\text { klauzule neplatí } \\
\text { pro s. menšin }\end{array}$ \\
\hline & 8. & 2008 & & 250 & 250 & PR List & 1 & 250 & D'Hondt & $5 \%, 0 \%$ & celostátní & \multicolumn{4}{|c|}{$x$} & $\begin{array}{l}\text { přísně } \\
\text { vázané }\end{array}$ & $\begin{array}{l}\text { klauzule neplatí } \\
\text { pro s. menšin }\end{array}$ \\
\hline & 9. & 2012 & & 250 & 250 & PR List & 1 & 250 & D'Hondt & $5 \%, 0 \%$ & celostátní & \multicolumn{4}{|c|}{$x$} & $\begin{array}{l}\text { přísně } \\
\text { vázané }\end{array}$ & $\begin{array}{l}\text { klauzule neplatí } \\
\text { pro s. menšin }\end{array}$ \\
\hline & 10. & 2014 & & 250 & 250 & PR List & 1 & 250 & D'Hondt & $5 \%, 0 \%$ & celostátní & \multicolumn{4}{|c|}{$x$} & $\begin{array}{l}\text { přísně } \\
\text { vázané }\end{array}$ & $\begin{array}{l}\text { klauzule neplatí } \\
\text { pro s. menšin }\end{array}$ \\
\hline MNE & 1. & 1990 & PR List & 125 & 125 & PR List & 20 & $\begin{array}{c}1,1,1,2,2,2,3 \\
3,4,4,5,5,5,5 \\
8,9,10,11,15 \\
29\end{array}$ & D'Hondt & $4 \%$ & celostátní & \multicolumn{5}{|r|}{$\begin{array}{l}\text { přísně } \\
\text { vázané }\end{array}$} & \\
\hline
\end{tabular}




\begin{tabular}{|c|c|c|c|c|c|c|c|c|c|c|c|c|}
\hline 2. & 1992 & 85 & 85 & PR List & 1 & 85 & D'Hondt & $4 \%$ & celostátní & $x$ & $\begin{array}{l}\text { přísně } \\
\text { vázané }\end{array}$ & \\
\hline 3. & 1996 & 71 & 71 & PR List & 14 & $\begin{array}{c}1,2,3,3,3,4, \\
4,4,5,5,5,6, \\
9,17 \\
\end{array}$ & D'Hondt & $4 \%$ & obvod & $x$ & $\begin{array}{l}\text { př́ísně } \\
\text { vázané }\end{array}$ & \\
\hline & & & 73 & & & & & & celostátní & $x$ & $\begin{array}{l}\text { príísně } \\
\text { vázané }\end{array}$ & \\
\hline 4. & 1998 & 78 & 5 & PR List & 1 & 78 & D'Hondt & $3 \%$ & obvod & $x$ & $\begin{array}{l}\text { prísně } \\
\text { vázané }\end{array}$ & $\begin{array}{l}\text { obvod pro } \\
\text { albánské strany }\end{array}$ \\
\hline 5 & 2001 & 77 & 72 & DP lict & 1 & 77 & D'Hondt & 20 & celostátní & $x$ & $\begin{array}{l}\text { přísně } \\
\text { vázané }\end{array}$ & \\
\hline כ. & 2001 & 17 & 5 & PK LISt & 1 & 11 & D honat & $3 \%$ & obvod & $x$ & $\begin{array}{l}\text { prísně } \\
\text { vázané }\end{array}$ & $\begin{array}{l}\text { obvod pro } \\
\text { albánské strany }\end{array}$ \\
\hline & & & 71 & & & & & & celostátní & $x$ & $\begin{array}{l}\text { prísně } \\
\text { vázané }\end{array}$ & \\
\hline 6. & 2002 & 75 & 4 & PR List & 1 & 75 & D'Hondt & $3 \%$ & obvod & $\mathrm{x}$ & $\begin{array}{l}\text { prísně } \\
\text { vázané }\end{array}$ & $\begin{array}{l}\text { obvod pro } \\
\text { albánské strany }\end{array}$ \\
\hline 7 & 2006 & 81 & 76 & DP L lict & 1 & 81 & $D^{\prime H}$ Hondt & $20 \%$ & celostátní & $x$ & $\begin{array}{l}\text { přísně } \\
\text { vázané }\end{array}$ & \\
\hline$\pi$. & 2006 & 81 & 5 & PR LISt & 1 & 81 & D Hondt & $3 \%$ & obvod & $x$ & $\begin{array}{l}\text { prísně } \\
\text { vázané }\end{array}$ & $\begin{array}{l}\text { obvod pro } \\
\text { albánské strany }\end{array}$ \\
\hline 0 & 2000 & 01 & 76 & 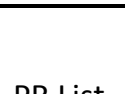 & & 01 & & & celostátní & $x$ & $\begin{array}{l}\text { přísně } \\
\text { vázané }\end{array}$ & \\
\hline 8. & 2009 & 81 & 5 & PR List & 1 & 81 & D'Hondt & $3 \%$ & obvod & $x$ & $\begin{array}{l}\text { prísnè } \\
\text { vázané }\end{array}$ & $\begin{array}{l}\text { obvod pro } \\
\text { albánské strany }\end{array}$ \\
\hline 0 & 2012 & 81 & 81 & PR list & 1 & 81 & $D^{\prime H}$ Hondt & $3 \%$ & celoctátní & $x$ & $\begin{array}{l}\text { přísně } \\
\text { vázané }\end{array}$ & \\
\hline 9. & 2012 & 81 & 81 & PR List & 1 & 81 & D'Hondt & $\begin{array}{c}0,7 \\
0,35 \%\end{array}$ & celostatnı & $x$ & $\begin{array}{l}\text { prísně } \\
\text { vázané }\end{array}$ & $*$ \\
\hline
\end{tabular}

* pokud žádná z albánských stran nepřekročí 3\%, jsou 3 mandáty rozděleny mezi strany s alespoň 0,7\%; 1 mandát pro chorvatské strany, pokud překročí 0,35\%

\begin{tabular}{|c|c|c|c|c|c|c|c|c|c|c|c|c|c|c|c|}
\hline \multirow{4}{*}{ RKS } & 1. & 2001 & \multirow{4}{*}{ PR list } & 120 & $\frac{100}{20}$ & PR List & 1 & 120 & $\begin{array}{l}\text { Saint- } \\
\text { Laguë }\end{array}$ & $x$ & $x$ & $x$ & $x$ & $\begin{array}{l}\text { přísně } \\
\text { vázané }\end{array}$ & $*$ \\
\hline & \multirow{2}{*}{2.} & \multirow{2}{*}{2004} & & \multirow{2}{*}{120} & 100 & \multirow{2}{*}{ PR List } & \multirow{2}{*}{1} & \multirow{2}{*}{120} & \multirow{2}{*}{$\begin{array}{l}\text { Saint- } \\
\text { Laguë }\end{array}$} & \multirow{2}{*}{$x$} & \multirow{2}{*}{$x$} & \multirow{2}{*}{$x$} & \multirow{2}{*}{$x$} & \multirow{2}{*}{$\begin{array}{l}\text { přísně } \\
\text { vázané }\end{array}$} & \\
\hline & & & & & 20 & & & & & & & & & & $*$ \\
\hline & 3. & 2007 & & 120 & 100 & PR List & 1 & 120 & $\begin{array}{l}\text { Saint- } \\
\text { Laguë }\end{array}$ & $5 \%$ & celostátní & $x$ & $x$ & flexibilní & $\begin{array}{l}\text { klauzule neplatí } \\
\text { pro s. menšin }\end{array}$ \\
\hline
\end{tabular}




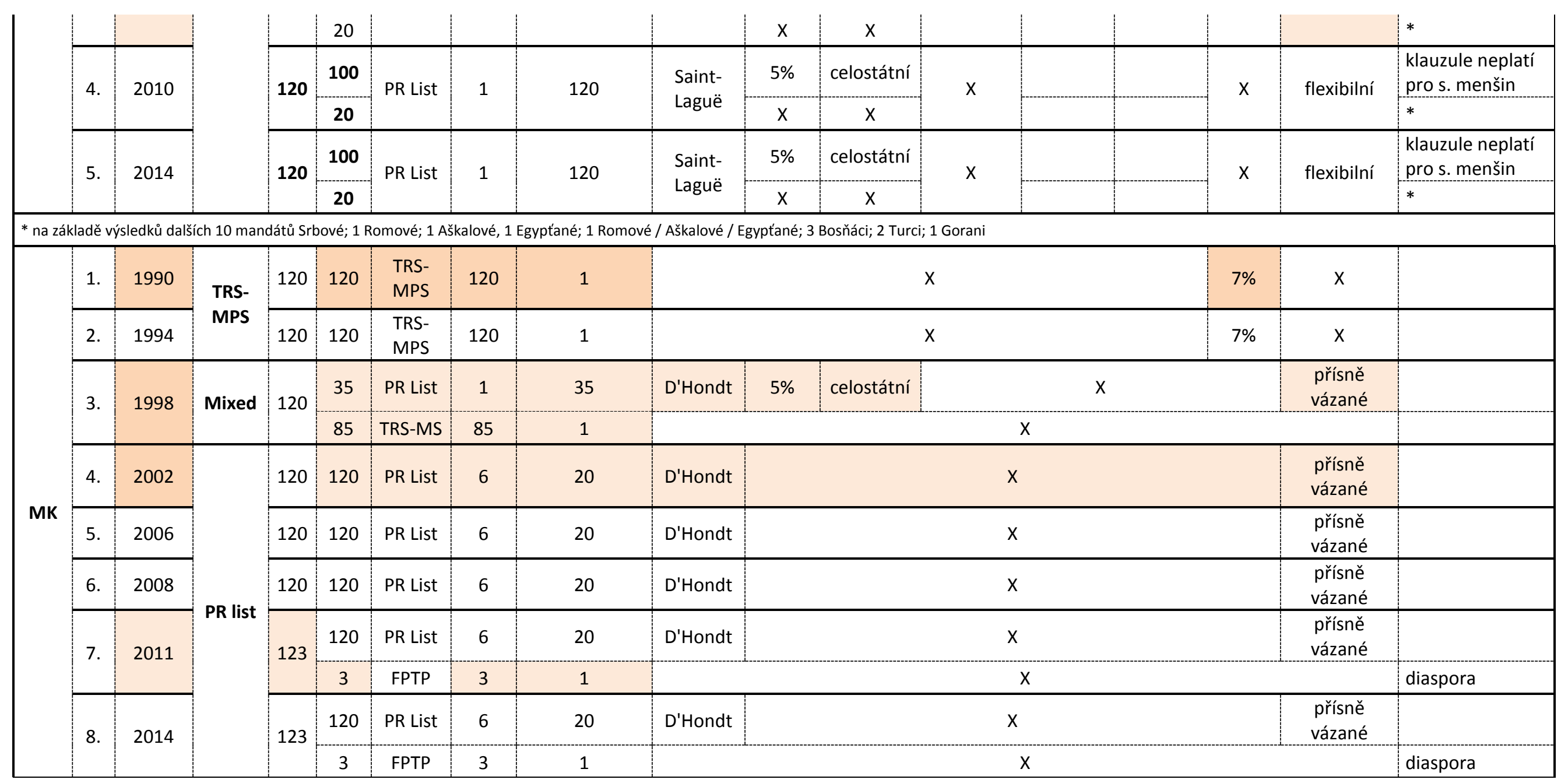

Zdroj: Autor. 